\title{
Administrative Severability Clauses
}

\begin{abstract}
A BSTRACT. Severability clauses can help administrative agencies minimize the damage caused by judicial review and can make the regulatory environment more efficient, participatory, and predictable. Yet agencies rarely include these clauses in their rules because courts tend to treat administrative rules with severability clauses the same as those without. Courts have treated administrative severability clauses in this way largely because they have mistakenly analogized them to severability clauses contained in statutes. While Congress routinely includes severability clauses in statutes that are drafted in distinct iterations, by different committees with legislative staff who often lack the time and expertise to consider the clauses' potential ramifications, administrative agencies use these clauses with more care. This Article proposes a Chevron-style deference framework for administrative severability clauses. Under this framework, after a reviewing court has set aside a challenged regulatory provision, the court should defer to a promulgating agency's opinion on severability as expressed through a severability clause, unless the remainder of the rule itself would suffer from legal defects resulting from the court's invalidation of the challenged provisions. This framework would better promote the overarching goals of administrative law than do current judicial doctrine and agency practice.
\end{abstract}

A UTHOR S. Charles W. Tyler is a law clerk to the Honorable Goodwin Liu, Associate Justice, Supreme Court of California; Yale Law School, J.D. 2013. E. Donald Elliott is Adjunct Professor of Law, Yale Law School, and Senior of Counsel, Covington \& Burling LLP. For their suggestions and encouragement, we thank Ali Deich, Arthur Ewenczyk, Heather Gerken, Abbe Gluck, Daniel Hemel, Chris Hu, Rob Katz, Daniel Markovits, Jerry Mashaw, Tracey Meares, Ben Moskowitz, Janice Ong, Nick Parrillo, Judith Resnik, Stan Richards, Rebecca Schonberg, Travis Silva, Andrew Tutt, and $\mathrm{Ke} \mathrm{Wu}$. The views set forth in this Article are the personal views of the authors alone and do not necessarily reflect the views of the institutions with which they are affiliated or their clients. 


\section{ARTICLE CONTENTS}

$\begin{array}{lr}\text { INTRODUCTION } & 2288\end{array}$

I. SEVERABILITY IN ADMINISTRATIVE LAW 2294

A. The Severability Decision $\quad 2294$

1. The Severability of Statutes 2294

2. The Severability of Administrative Rules 2296

B. The Who-Decides Question 2297

1. Agency Intent 2298

2. Workability of the Remainder 2299

a. Expertise 2299

b. Accountability $\quad 2301$

c. Rule of Law 2306

d. Efficiency 2309

II. THE STRANGE DEARTH OF ADMINISTRATIVE SEVERABILITY CLAUSES 2312

A. De Novo Review by the Courts 2312

B. Neglect in the Agencies $\quad 2318$

III. DEFERENCE TO ADMINISTRATIVE SEVERABILITY CLAUSES 2324

A. Disassociating Statutory and Administrative Severability Clauses $\quad 2324$

1. Attention Paid to Severability Clauses 2326

2. Time Pressure $\quad 2327$

3. Centralization $\quad 2329$

B. A Chevron-Style Framework for Severability Clauses 2331

1. Step One: Address Legal Defects 2334

a. Identifying Defects 2335

b. Remedying Defects 2338

2. Step Two: Defer to the Agency 2341

3. Step Zero: The Limits of the Deference Framework 2344

$\begin{array}{lr}\text { CONCLUSION } & 2348\end{array}$

APPENDIX: ADMINISTRATIVE SEVERABILITY CLAUSES BY AGENCY 2349 


\section{INTRODUCTION}

"Judicial review controls administrative action in the same way that tornadoes control the rice crop in Arkansas: they appear unpredictably, wreak havoc, and then depart."

- Jerry Mashaw ${ }^{1}$

This Article explores a topic overlooked in legal scholarship: severability clauses in administrative regulations. "Administrative severability clauses," as we call them, are provisions of administrative rules that clarify whether an agency intends for a rule to remain in effect if a court were to invalidate a portion of the rule. ${ }^{2}$ A recent example, to which we return at several points in the Article, helps to illustrate the function and potential importance of these clauses.

The Environmental Protection Agency (EPA) recently published a proposed rule, commonly referred to as the "Clean Power Plan." 3 Political analysts have dubbed it the "centerpiece" of the Obama Administration's strategy on climate change. ${ }^{4}$ The Clean Power Plan aspires to reduce greenhouse gas emissions by thirty percent below 2005 levels before 2030 by requiring states to

1. This is a paraphrase of a remark often ascribed to Jerry Mashaw. The remark always connects natural disasters with vegetation. Sometimes it is about tornadoes controlling rice crops, sometimes forest fires controlling the underbrush, but the point is always the same: judicial review is "both stochastic and destructive." Email from Jerry Mashaw, Sterling Professor of Law, Yale Law Sch., to Charles Tyler, J.D. 2013, Yale Law Sch. (Dec. 24, 2014, 08:08 EST) (on file with author); see also JERRY L. MASHAW \& DAVID L. HARFST, THE STRUGGLE FOR AUTO SAFETY 10-14 (1990); Jerry L. Mashaw, Improving the Environment of Agency Rulemaking: An Essay on Management, Games, and Accountability, 57 LAW \& CONTEMP. PROBS. 185, 200-04 (1994).

2. When we refer to administrative "rules" in this Article, we mean legislative rules, usually adopted through notice and comment. Although a severability clause is usually contained in the regulatory text, some agencies indicate that a rule is severable in the rule's statement of basis and purpose. See, e.g., Applications for FDA Approval To Market a New Drug: Patent Submission and Listing Requirements, 68 Fed. Reg. 36,676, 36,695-96 (June 18, 2003) (to be codified at 21 C.F.R. pt. 314). Where possible, we have counted these remarks as severability clauses because they have many of the same benefits as severability clauses included in a rule's text.

3. See Carbon Pollution Emission Guidelines for Existing Stationary Sources: Electric Utility Generating Units, 79 Fed. Reg. 34,830, 34,832 (proposed June 18, 2014) (to be codified at 40 C.F.R. pt. 6o) [hereinafter Carbon Pollution Emission Guidelines].

4. Editorial, The EPA's Emissions Plan Should Be Just the Beginning, WASH. POST, June 2, 2014, http://www.washingtonpost.com/opinions/the-epas-emissions-plan-should-be-just-the-be ginning/2014/o6/o2/640cd838-ea9a-11e3-9f5c-9075d5508foa_story.html [http://perma.ce /ND94-6933]. 
meet certain carbon pollution emissions goals. ${ }^{5}$ To set those goals, the EPA has identified four measures, which the proposed rule terms "building blocks" and which the agency has determined together make up the "best system of emission reduction." The building blocks are: (1) making existing coal plants more efficient; (2) using existing gas plants more effectively; (3) increasing reliance on renewable and nuclear energy sources; and (4) improving end-use energy efficiency. ${ }^{7}$ Like many environmental regulations, the Clean Power Plan is an example of cooperative federalism. While states are free to formulate their own plans for reducing greenhouse gas emissions, they must implement plans that will at least match the emissions reductions that the EPA has determined could be achieved by implementing the four building blocks.

Since the EPA's emissions goals are derived from the building blocks, regulated entities opposed to the Clean Power Plan - and there are many-are likely to challenge the building blocks in court. The agency may therefore be concerned that a court will vacate the entire Clean Power Plan if a court finds that just one of the building blocks is invalid. Likely in order to manage this risk, the EPA inserted a severability clause into the proposed rule's text. The clause provides that if a court invalidates one or more of the building blocks, the remainder of the rule should stay in effect, and the states' adjusted emissions targets should be based on the remainder of the building blocks. ${ }^{8}$

The Clean Power Plan's severability clause will become relevant in litigation if a discontent stakeholder challenges the rule and the reviewing court sets one or more of the building blocks aside. The court will then have to make what we call the "severability decision"; it will have to choose between invalidating only the challenged provision, invalidating the challenged provision and several other provisions, or invalidating the entire rule.

In the absence of the severability clause, the severability decision requires a reviewing court to apply a fairly well-established doctrinal framework. But

5. Carbon Pollution Emission Guidelines, supra note 3 , at 34,832 .

6. Id. at 34,836 .

7. Id.

8. The severability clause reads:

We consider our proposed findings of the BSER [Best System of Emission Reduction] with respect to the various building blocks to be severable, such that in the event a court were to invalidate our finding with respect to any particular building block, we would find that the BSER consists of the remaining building blocks. The state goals that would result from any combination of the building blocks can be computed from data included in the Goal Computation TSD [Technical Support Document] and its appendices using the methodology described in the preamble and that TSD.

Id. at 34,892 . 
when a rule contains a severability clause, such as the one contained in the Clean Power Plan, it raises an important question that courts and commentators have largely overlooked. Who should decide whether an invalidated provision of a rule is severable? We call this the "who-decides question." The whodecides question implicates the level of deference that a reviewing court should give to a promulgating agency's opinion on the severability of a rule expressed in a severability clause.

Once raised, the who-decides question involves some of the most basic issues in administrative law-issues about the allocation of decision-making authority in the federal government. When an agency has expressed its view on severability, should a court defer to the agency, as it would when an agency reasonably interprets an ambiguous statute pursuant to a congressional delega-

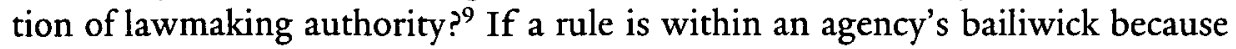
it was promulgated pursuant to a statutory delegation of authority, does the severability of the rule also fall within its bailiwick, or is the severability decision intrinsically within the judicial power? Does a severability clause constitute an interpretation of the agency's own rule, qualifying it for Seminole Rock deference (that is, deference accorded to an agency's interpretation of its own regulations) ? ${ }^{\text {10 }}$ If courts should give some measure of deference to an agency's opinion on severability, how much? Do some of the agency's statements on severability, but not others, deserve deference?

The visibility of the Clean Power Plan's severability clause notwithstanding, these questions remain mostly under-theorized. Until the last two decades, only three articles had been devoted to severability doctrine in either statutes or rules. ${ }^{11}$ And courts have analyzed the doctrine in little more depth. Former Chief Judge of the Ninth Circuit John Clifford Wallace once lamented that "[t]he test for severability has been stated often but rarely explained." ${ }^{12}$ To be sure, theoretical analysis of the severability of statutes has become more robust in recent years. The severability doctrine has figured prominently in recent de-

9. See Chevron U.S.A., Inc. v. Natural Res. Def. Council, 467 U.S. 837, 843-44 (1984); see also United States v. Mead Corp., 533 U.S. 218 (2001).

10. See Bowles v. Seminole Rock \& Sand Co., 325 U.S. 410, 414 (1945); see also Auer v. Robbins, 519 U.S. 452, 461 (1997) (holding that the agency's interpretation is controlling unless it is "plainly erroneous or inconsistent with the regulation") (internal quotation marks omitted).

11. See Mark L. Movsesian, Severability in Statutes and Contracts, 30 GA. L. Rev. 41 (1995); John Copeland Nagle, Severability, 72 N.C. L. REv. 203 (1993); Robert L. Stern, Separability and Separability Clauses in the Supreme Court, 51 HARv. L. ReV. 76 (1937).

12. Nagle, supra note 11, at 205 (quoting Bd. of Natural Res. v. Brown, 992 F.2d 937, 947 (9th Cir. 1993)). 
bates in both Congress ${ }^{13}$ and the Supreme Court, ${ }^{14}$ and scholars have responded with full articles on the subject. ${ }^{15}$ But the analysis of administrative severability doctrine continues to lag behind. There have been no law review articles addressing severability in administrative law, and we have found only one secondary source even mentioning the difference between the severability analyses in the statutory and administrative contexts. ${ }^{16}$

The dearth of scholarship is probably due, in part, to the answer that the agencies and the courts currently give to the who-decides question. Agencies tend to include severability clauses in their rules infrequently and sporadically. Even when an agency does include a severability clause in a rule, the current doctrine suggests that a reviewing court should not defer to it. Thus, the current judicial doctrine and agency practice regarding administrative severability represents one possible allocation of decision-making authority: namely, courts make the severability decision de novo without regard to the existence of a severability clause. As a result, these relatively insignificant clauses have not received much attention from commentators.

This Article maintains that current judicial doctrine and agency practice regarding severability are misguided. We think that courts should defer to administrative severability clauses and that agencies should more frequently include them in their rules. We propose a deference framework for

13. In a widely covered dispute, Congress debated the inclusion of either a severability clause or a nonseverability clause in the Bipartisan Campaign Reform Act of 2002. See Excerpts From Senate Debate on Donations: Skirmishing and Predictions, N.Y. TIMES, Mar. 30, 2001, http:// www.nytimes.com/2001/03/30/us/excerpts-from-senate-debate-on-donations-skirmishing -and-predictions.html [http://perma.cc/AA47-RVQC].

14. The Court has addressed the severability doctrine in several recent cases, including: Executive Benefits Insurance Agency v. Arkison, 134 S. Ct. 2165, 2173 (2014); National Federation of Independent Business v. Sebelius, 132 S. Ct. 2566 (2012); Free Enterprise Fund v. Public Co. Accounting Oversight Board, 561 U.S. 477 (2010); and Ayotte v. Planned Parenthood of Northern New England, 546 U.S. 320 (2006).

15. See Tom Campbell, Severability of Statutes, 62 HAstings L.J. 1495 (2011); Michael C. Dorf, Fallback Law, 107 Colum. L. REV. 303 (2007); Tobias A. Dorsey, Remarks, Sense and Severability, 46 U. RuCH. L. REv. 877 (2012); Fred Kameny, Are Inseverability Clauses Constitutional?, 68 ALB. L. REV. 997 (2005); Kenneth A. Klukowski, Severability Doctrine: How Much of a Statute Should Federal Courts Invalidate?, 16 TEX. REV. L. \& POL. 1 (2011); Michael D. Shumsky, Severability, Inseverability, and the Rule of Law, 41 HARV. J. ON LEGIS. 227 (2004); Kevin C. Walsh, Partial Unconstitutionality, 85 N.Y.U. L. REV. 738 (2010); Rachel J. Ezzell, Note, Statutory Interdependence in Severability Analysis, 111 MICH. L. REV. 1481 (2013); C. Vered Jona, Note, Cleaning Up for Congress: Why Courts Should Reject the Presumption of Severability in the Face of Intentionally Unconstitutional Legislation, 76 GEO. WASH. L. REV. 698 (2008); Jenna L. Kamiat, Comment, PPACA and the Individual Mandate: A Healthy Approach to Severability, 80 FORDHAM L. REV. 2237 (2012).

16. See Ronald M. Levin, "Vacation" at Sea: Judicial Remedies and Equitable Discretion in Administrative Law, 53 DUKE L.J. 291, 330 (2003). 
administrative severability clauses, similar to the Chevron and Seminole Rock frameworks, under which both courts and agencies would play a role in the severability decision.

This Article proceeds in three Parts. Part I explains the severability decision and the who-decides question in more detail. In Part I.A, we discuss the current severability doctrine. As we explain, the doctrinal test for severability consists of two questions: (1) whether the promulgating agency would have intended for the remainder of a regulation to stay in effect; and (2) whether the remainder of the regulation is workable.

In Part I.B, we consider which institution-the reviewing court or the promulgating agency-is best suited to answer each of these questions. We conclude that when a promulgating agency has expressed an opinion on severability through a severability clause, it has offered an answer to the intent and workability questions. Because the promulgating agency is better equipped than a court to assess both its own intent on severability and the workability of a regulatory remainder, the agency's answers to those questions deserve deference. This preliminary discussion will serve as helpful background for our thesis that the current doctrine and practice on severability clauses misallocates decision-making authority and for our proposal of a deference framework for administrative severability clauses.

Part II describes the current judicial doctrine and agency practice on administrative severability clauses and shows that the doctrine and practice do not follow the allocation of decision-making authority suggested in Part I. In Part II.A, we explain that federal courts for decades have declined to take severability clauses in statutes at face value. We then explain that the doctrinal treatment of statutory severability clauses has been applied to administrative severability clauses because courts have reflexively analogized the two.

In Part II.B, we explain that agencies do not generally include severability clauses in their rules. Instead, agencies usually offer their opinions on severability only when required to do so in litigation. Our research suggests that agencies behave in this way because promulgating severability clauses through notice-and-comment procedures often entails significant ex ante and ex post costs that courts do not reward through greater deference. In light of the discussion in Part I, we conclude that judicial doctrine and agency practice regarding severability are misguided. Courts should develop a framework for deferring to administrative severability clauses that would create greater incentives for agencies to include severability clauses in their rules.

Part III outlines our proposed deference framework for administrative severability clauses. In Part III.A, we debunk the primary doctrinal obstacle to such a framework. We argue that it is a mistake to evaluate administrative severability clauses through the same prism used to evaluate statutory severability clauses. Congress and the agencies have different institutional capacities and 
incentives. In Congress, severability clauses are often thrown in to far-reaching statutes that are drafted in several iterations, by several committees with legislative staff members who often lack the time and expertise to consider the clauses' potential ramifications adequately. By contrast, administrative agencies are more unified organizations that operate in a narrower regulatory space and have staff with greater expertise; agencies can therefore devote more resources to considering the potential consequences of a severability clause. As a result, administrative severability clauses are a more useful guide to the severability decision than statutory severability clauses. The analogy between statutory and administrative severability clauses is thus misplaced.

In Part III.B, we articulate a framework that courts can use to evaluate whether to sever an invalid provision from a rule containing a severability clause. When a court invalidates a provision of an administrative rule containing a severability clause, the court should first determine whether the remainder of the rule contains residual legal defects. For example, the court should determine whether the remainder of the rule is unconstitutional, ultra vires, arbitrary and capricious, or otherwise unlawful. If possible, the court should remove those residual legal defects by setting aside additional provisions of the rule. The court, however, should defer to the agency's severability decision if it determines that the remainder does not contain inextricable, residual legal defects. We also argue that courts should give Chevron-style deference only to administrative severability clauses, rather than informal agency opinions on severability. We acknowledge that agencies should be provided with some incentive to opine on severability before litigation commences because informal agency opinions on severability will often be better than no opinion at all. To encourage agencies to clarify their positions on severability, even if not through notice-and-comment procedures, we propose that courts give Skidmore deference to informal agency actions, such as litigation briefs, that opine on severability. ${ }^{17}$

The use of severability clauses in regulations is a fairly nascent experiment in administrative law. While the case law on these devices is problematic, it is not so entrenched that it could not easily be changed by a panel of the U.S. Court of Appeals for the District of Columbia Circuit (D.C. Circuit) or the U.S. Supreme Court. This Article shows that deference to severability clauses in rules would have significant benefits for complex and ambitious regulatory schemes like the EPA's Clean Power Plan. Since the EPA is scheduled to promulgate the final rule implementing the Plan in the summer of 2015, now is an auspicious time for the courts to reconsider their approach to administrative severability clauses.

17. Skidmore v. Swift \& Co., 323 U.S. 134 (1944). 


\section{SEVERABILITY IN ADMINISTRATIVE LAW}

\section{A. The Severability Decision}

Questions of severability arise after a discontented stakeholder challenges a provision of a statute or regulation and the reviewing court invalidates the challenged provision as unconstitutional, ultra vires, arbitrary and capricious, supported by insubstantial evidence, or otherwise unlawful. Having invalidated the challenged provision, the reviewing court's scrutiny turns to what we call the statutory or regulatory "remainder" - the part of the statute or rule that would remain absent the invalid provision. Assessing the remainder gives rise to the severability decision - the remedial choice between invalidating the challenged provision alone, the challenged provision and some of the remainder, or the entire statute or rule.

Courts and commentators have spent a good amount of time and energy theorizing the severability decision. The Supreme Court has developed a fairly useful test for making that decision. That test was first developed as the Court considered the severability of congressional statutes. But, as we shall see, the Supreme Court and the D.C. Circuit have repurposed the test for use in determining the severability of administrative regulations.

\section{The Severability of Statutes}

The leading case laying out the Court's modern severability doctrine is Alaska Airlines, Inc. v. Brock. ${ }^{18}$ In that case, several airlines challenged the employee protection program provisions of the Airline Deregulation Act. ${ }^{19}$ Following the Court's landmark decision in Chadha, ${ }^{20}$ which held legislative veto provisions unconstitutional, the Court held that the Deregulation Act's legislative veto provision was unconstitutional and that the challenged provision was severable from the statutory remainder. ${ }^{21}$ Writing for the Court, Justice Blackmun explained: "Unless [1] it is evident that the Legislature would not have enacted those provisions which are within its power, independently of

18. 480 U.S. 678,684 (1987). Alaska Airlines synthesized tests developed in earlier cases. See Regan v. Time, Inc., 468 U.S. 641, 653 (1984); INS v. Chadha, 462 U.S. 919, 931-32 (1983); Buckley v. Valeo, 424 U.S. 1, 108 (1976); United States v. Jackson, 390 U.S. 570, 585 (1968); Champlin Ref. Co. v. Corp. Comm'n of Oklahoma, 286 U.S. 210, 234 (1932).

19. Alaska Airlines, 480 U.S. at 680 .

20. Chadha, 462 U.S. 919. For criticism of the Chadha opinion, see E. Donald Elliott, INS v. Chadha: The Administrative Constitution, the Constitution, and the Legislative Veto, 1983 SUP. CT. REv. 125 .

21. Alaska Airlines, 480 U.S. at 683 . 
that which is not, the invalid part may be dropped if [2] what is left is fully operative as a law."22 Alaska Airlines holds that courts should ask two questions when considering how to remedy invalid statutory provisions. ${ }^{23}$

First, would Congress have enacted the remainder without the unlawful provision? Call this the "intent question." To answer this question, the reviewing court investigates Congress's intent at the time it enacted the relevant statute. Ideally, the reviewing court would find evidence of Congress's actual intent-that is, evidence that Congress considered the possibility that the challenged provision would be struck down and intended the remainder of the statute to stay in effect (or not) under those circumstances. Evidence of actual intent, however, is often unavailable. In the absence of such evidence, courts look for evidence of putative intent - that is, evidence of what Congress would have wanted had it thought about the possibility that the challenged provision would be struck down. So the intent question often requires a counterfactual inquiry. It requires the reviewing court to recreate the bargain between stakeholders that led to the statute's final text to determine what the lawmakers likely would have wanted had they known that the reviewing court would strike down the challenged provision. ${ }^{24}$

The second question that courts are required to ask is whether the statutory remainder is "fully operative as a law." In other words, is the remainder workable? Call this the "workability question." To answer this question, the court must determine whether the statute is "capable of functioning independently" of the challenged provision. ${ }^{25}$ Often courts answering this question will consider the interdependence of the relevant statute's provisions. If the reviewing court answers either question in the negative, it will strike down the entire statute.

22. Id. at 684 (quoting Buckley v. Valeo, 424 U.S. 1, 108 (1976) (per curiam) (internal quotation marks omitted)).

23. The Court's recent cases dealing with severability have followed the Alaska Airlines test. See, e.g., Exec. Benefits Ins. Agency v. Arkison, 134 S. Ct. 2165, 2173 (2014); Free Enterprise Fund v. Public Co. Accounting Oversight Bd., 561 U.S. 477, 509 (2010).

24. See, e.g., Alaska Airlines, 480 U.S. at 697 (stating that the legislative veto was not essential to the legislative bargain over the Airline Deregulation Act); City of New Haven v. United States, 809 F.2d 900, 907 (D.C. Cir. 1987); Atkins v. United States, 556 F.2d 1028, 1086 (Ct. Cl. 1977).

25. Alaska Airlines, 480 U.S. at 684 ("Congress could not have intended a constitutionally flawed provision to be severed from the remainder of the statute if the balance of the legislation is incapable of functioning independently."). 


\section{The Severability of Administrative Rules}

The Court's test for the severability of administrative regulations repurposes the Alaska Airlines statutory severability test. The first Supreme Court case to assess the severability of administrative regulations was $K$-Mart Corp. v. Cartier, where the Court considered whether a subsection of a Customs Service regulation violated the Tariff Act of $1930 .{ }^{26}$ The Tariff Act prohibited the importation of foreign merchandise bearing a trademark owned by a United States' citizen (or a corporation organized within the United States) without the owner's written consent. The Customs Service regulation permitted foreign manufacturers to import trademarked goods into the United States if they had received the U.S. trademark owner's authorization to use its trademark, but not necessarily its authorization to import goods bearing the trademark into the United States. ${ }^{27}$ The Court held that the regulation violated the Tariff Act. ${ }^{28}$ Writing for the majority, Justice Kennedy reasoned that the invalid subsection of the Customs Service regulation was severable from the remainder because invalidating the subsection would "not impair the function of the statute as a whole" and because "there is no indication that the regulation would not have been passed but for its inclusion." Although Justice Kennedy's analysis did not cite any cases, he applied the same test for the severability of statutes that the Court had articulated in Alaska Airlines just one year earlier.

Since the $K$-Mart decision, courts have applied the same test to determine the severability of administrative provisions and the severability of statutory provisions..$^{30}$ For example, in Davis County Solid Waste Management $v$. EPA, the

26. 486 U.S. $281,286-93$ (discussing 46 Stat. 741 (codified as amended at 19 U.S.C. $\$ 1526$ (2012))).

27. Id. at 290 (discussing 19 C.F.R. $\$ 133.21(\mathrm{c})(3)(1987)$ ).

28. Id. at 291.

29. Id. at 294 .

30. For cases where the D.C. Circuit and the U.S. District Court in that Circuit have cited $K$ Mart on the severability decision, see Fin. Planning Ass'n v. SEC, 482 F. $3 \mathrm{~d} 481,493$ (D.C. Cir. 2007); MD/DC/DE Broadcasters Ass'n v. FCC, 236 F.3d 13, 22 (D.C. Cir. 2001); Virginia v. EPA, 116 F.3d 499, 501 (D.C. Cir. 1997); Davis Cnty. Solid Waste Mgmt. v. EPA (Davis County II), 108 F.3d 1454, 1460 (D.C. Cir. 1997); Alliance for Cmty. Media v. FCC, 10 F.3d 812, 830 (D.C. Cir. 1993), reh'g en banc granted, judgment vacated 15 F.3d 186 (D.C. Cir. 1994); and Akiachak Native Cmty. v. Jewell, 995 F. Supp. 2d 1, 5-6 (D.D.C. 2013). The D.C. Circuit has decided several recent cases addressing the severability of administrative regulations on the intent prong alone, without resorting to the workability prong. See, e.g., North Carolina v. EPA, 531 F.3d 896, 929 (D.C. Cir. 2008); New Jersey v. EPA, 517 F.3d 574, 584 (D.C. Cir. 2008); Nat'l Treasury Emps. Union v. Chertoff, 452 F.3d 839, 867 (D.C. Cir. 2006). The D.C. Circuit has given no indication, however, that severability no longer depends on the second prong. 
D.C. Circuit reconsidered the issue of whether an invalid provision of an EPA rule could be severed from the remainder of the rule. ${ }^{31}$ As in the case of statutes, the court held that severability depends on: (1) whether there is any " indication that the regulation would not have been passed but for [the] inclusion' of the [invalid] standards" and (2) whether severance would "impair the function of [the remainder of the rule]." 32 Here again, severability was made to depend on the intent and workability questions.

\section{B. The Who-Decides Question}

The current severability doctrine may be useful for making the severability decision when an agency has not included a severability clause in its rule. But courts and commentators have generally not considered which institution should make that decision when an agency has included a severability clause in a rule. This is the who-decides question.

Perhaps the simple answer to the who-decides question is that the reviewing court must decide. After all, the severability decision concerns a remedial issue in litigation. Courts are the "tornadoes," in Mashaw's analogy, and they must determine what is left in their wake. ${ }^{33}$ But this simplistic answer overlooks the ways in which a severability clause could affect a reviewing court's severability analysis.

When an agency includes a severability clause in a rule, it states whether it would promulgate the rule without certain portions. More specifically, a severability clause can be seen as the agency's affirmative answer to the two component questions of the severability test: the agency (1) intends for the remainder to stay in effect; and (2) believes that the remainder is workable. In light of the agency's opinion on severability, the question becomes whether a reviewing court should defer to that opinion or substitute its own judgment for that of the agency.

In this way, when an agency has included a severability clause in a rule, the who-decides question raises questions familiar from scholarly discussions of the Chevron doctrine. Just as we need a doctrine for determining whether a reviewing court should defer to an agency's interpretation of a federal statute, so too we need a doctrine for determining whether a reviewing court should defer to an agency's opinion on severability expressed through a severability clause. We now consider whether a reviewing court should defer to a promulgating agency's answer to the intent and workability questions.

\footnotetext{
31. Davis County II, 108 F.3d at 1455.

32. Id. at 1460 (quoting $K-M a r t, 486$ U.S. at 294).

33. See supra note 1 and accompanying text.
} 


\section{Agency Intent}

The first question for the reviewing court to consider is whether the promulgating agency would have wanted the remainder to stay in effect had it contemplated that a court would invalidate the challenged provision. ${ }^{34}$ On its face, an administrative severability clause is the agency's affirmative answer to that question. ${ }^{35}$ A typical administrative severability clause, for example, reads as follows: "The provisions of this part are separate and severable from one another. If any provision is stayed or determined to be invalid, it is the Commission's intention that the remaining provisions shall continue in effect." ${ }^{36}$

The case for judicial deference on the intent question is straightforward. The regulatory text is strong evidence of the agency's intent. ${ }^{37}$ When an administrative rule contains a severability clause, it is odd for a court to conduct an independent inquiry into whether the agency intended for the remainder to stay in effect. To do so amounts to a search for the agency's putative intent when the rule already contains a statement of the agency's actual intent.

Moreover, when a court searches for putative intent under these circumstances, it likely lacks a coherent objective. Recall that the inquiry into an agency's putative intent attempts to recreate the bargain between stakeholders that gave rise to the regulation. But the court must suppose that the severability clause, as part of the regulatory text, is itself part of the regulatory bargain. ${ }^{38}$ It

34. Davis County II, 108 F.3d at 1459 (quoting North Carolina v. FERC, 730 F.2d 790, 795-96 (D.C. Cir. 1984)) ("Whether an administrative agency's order or regulation is severable . . depends on the issuing agency's intent.").

35. Cf. David H. Gans, Severability as Judicial Lawmaking, 76 GEO. WASH. L. REV. 639, 649 n.51 (2008) (suggesting that severability clauses "settle, once and for all, the question of legislative intent"). For similar reasons, some commentators have argued for a plain meaning rule for statutory severability clauses. See Movsesian, supra note 11, at 73-82; Nagle, supra note 11, at 234-46; Shumsky, supra note 15, at 245-67.

36. FTC Children's Online Privacy Protection Rule, 16 C.F.R. $\$ 312.13$ (2014) (emphasis added); see also 70 Fed. Reg. 25,654, 25,656 (May 13, 2005) (codified at 36 C.F.R. $\$ 294.18$ ) ("The Department wishes to make its intent clear that should all or any part of this regulation be set aside, the Department does not intend that the prior rule be reinstated, in whole or in part.") (emphasis added); Applications for FDA Approval To Market a New Drug: Patent Submission and Listing Requirements and Application of 30-Month Stays on Approval of Abbreviated New Drug Applications Certifying that a Patent Claiming a Drug Is Invalid or Will Not Be Infringed, 68 Fed. Reg. 36,695-96 (2003) (codified at 21 C.F.R. $\$ 314$ ).

37. See generally John F. Manning, The New Purposivism, 2011 SUP. CT. REV. 113 (describing the modern "textually structured approach to purposivism"); Kevin M. Stack, Interpreting Regulations, 111 MICH. L. REV. 355 (2012).

38. Indeed, some severability clauses recognize the importance of a regulatory provision while providing that the provision is nonetheless severable from the remainder. For example, in one rule's statement of basis and purpose, the FCC commented: 
is therefore questionable whether the court could properly find that the regulatory bargain implies that the challenged provision is inseverable. Consequently, we think there is a compelling case for judicial deference to the plain meaning of a severability clause with respect to the promulgating agency's intent.

\section{Workability of the Remainder}

The second question for the reviewing court to consider is whether the remainder is workable. Unlike the intent question, severability clauses do not always address this aspect of the severability decision expressly. Still, it is fair to read a severability clause as providing the agency's opinion on workability because workability is such a prominent consideration - perhaps the most prominent consideration -in the severability decision. Therefore, like the intent question, courts should give deference to the agency's opinion on workability when it is expressed in a severability clause. Below, we provide four reasons that the regulatory environment would benefit if courts gave deference to the agency's answer to the workability question, expressed through an administrative severability clause.

\section{a. Expertise}

Agencies are often better equipped than courts to determine whether a regulatory remainder is workable because they have greater subject-matter expertise. Agency expertise has several sources. First, agencies are highly specialized. Federal agencies are differentiated by subject matter, and each agency's staff spends most of its time and resources addressing issues related to the agency's particular substantive domain. As a result, the staff becomes more knowledge-

\footnotetext{
We remind stations and MVPDs that they must always utilize their audio passthrough equipment so that it does not harm the RP-compliant programming they receive and transmit to their viewers. We note that this safe harbor is an important but severable element of our compliance and enforcement scheme. We are establishing it to simplify our enforcement process for the benefit of stations and MVPDs, but it is not so fundamental to the scheme as a whole that the CALM Act regulations adopted in the item would be unenforceable in its absence. If the safe harbor is declared invalid or unenforceable for any reason, it is our intent that the remaining CALM Act regulations shall remain in full force and effect.
}

Implementation of the Commercial Advertisement Loudness Mitigation (CALM) Act, 77 Fed. Reg. 40,276, 40,285 n.132 (July 9, 2012) (codified at 47 C.F.R. $\$ \$ 73,76$ ) (emphasis added). 
able about the policies and methods that work in that domain. ${ }^{39}$ Second, agency personnel usually include staff members who have advanced training in fields such as economic analysis and the scientific disciplines. The EPA's staff, for example, includes scientists and economists tasked with evaluating the EPA's regulatory and enforcement efforts. Similarly, the Securities and Exchange Commission employs economists and lawyers with advanced training in economics to determine the best rules for detecting and preventing securities fraud. ${ }^{40}$ Finally, executive-branch agencies are subject to review by the Office of Information and Regulatory Affairs (OIRA), whose staff of economists and other experts requires agencies to justify major rulemakings through costbenefit analysis. ${ }^{41}$ "[J]udges," by contrast, "are not expert in the field." ${ }^{22}$ They are generalists who decide cases across various subject matters. Judges also have relatively limited resources and staff who rarely have highly advanced training in economics and related disciplines. Finally, courts have limited investigative powers and must decide each case based on the facts that are presented by the parties.

An agency's superior subject-matter expertise typically means that the agency is better able than courts to make informed policy judgments. This is one reason why, under Chevron, a reviewing court will defer to an agency's reasonable interpretation of an ambiguous statute that the agency is charged with implementing. Similarly, agencies are better equipped to determine whether a regulatory remainder is workable because, in many instances, this inquiry requires a deep understanding of the subject matter of the regulation itself.

Consider, for example, the Clean Power Plan. As explained above, the Plan sets carbon pollution emissions goals for the states by identifying four "building blocks," which the agency has determined together make up the "best system of emission reduction." 43 The Plan's severability clause provides that if a court sets aside any of the building blocks, then the remainder of the Plan

39. William N. Eskridge, Jr., Expanding Chevron's Domain: A Comparative Institutional Analysis of the Relative Competence of Courts and Agencies To Interpret Statutes, 2013 WIS. L. REV. 411, 421.

40. Id. at 422.

41. Id. at 422; Nicholas Bagley \& Richard L. Revesz, Centralized Oversight of the Regulatory State, 106 Colum. L. REv. 1260, 1268-70 (2006); Steven Croley, White House Review of Agency Rulemaking: An Empirical Investigation, 70 U. CHI. L. REV. 821, 821-30 (2003); Thomas O. McGarity, A Cost-Benefit State, so ADMIN. L. REV. 7, 40-48 (1998); Cass R. Sunstein, The Office of Information and Regulatory Affairs: Myths and Realities, 126 HARV. L. REV. 1838, 184454 (2013).

42. Chevron, U.S.A., Inc. v. Natural Res. Def. Council, Inc., 467 U.S. 837, 865-66 (1984).

43. Carbon Pollution Emissions Guidelines for Existing Stationary Sources: Electric Utility Generating Units, 79 Fed. Reg. 34,830, 34,835 (June 18, 2014) (to be codified at 40 C.F.R. pt. 6o). 
should stay in effect. ${ }^{44}$ If a federal court invalidates one of the building blocks, the court must determine whether the remainder of the regulation is workable in the absence of the invalid provision. This inquiry inherently involves determining whether the remaining building blocks could sensibly be thought to constitute the "best system of emission reduction." ${ }^{\text {.4 }}$ Put plainly, this is a question that the EPA-the agency with experience implementing the Clean Air Act - is best equipped to answer. ${ }^{46}$

The Clean Power Plan is not unique in this respect. Many regulatory schemes are very technical and complex, and they often involve highly interdependent provisions. ${ }^{47}$ In fact, every indication is that regulatory schemes are becoming more complex each year. ${ }^{48}$ Further, as we explain below, agencies rarely use severability clauses. Thus, when an agency does include a severability clause in a rule, it may indicate that the rule is especially technical and complex and that the agency fears that a court may incorrectly associate complexity with the rule's supposed inability to function absent a challenged provision.

In light of the highly technical and complex nature of modern regulation and the agency practice of only rarely including severability clauses in rules, generalist judges should defer to an expert agency that has offered its opinion through an administrative severability clause on the workability of a regulatory remainder. A court should not substitute its policy judgment for the agency's. ${ }^{49}$ Instead, courts should defer to the expert agency's opinion on whether the remainder is workable.

\section{b. Accountability}

Deference to the agency's answer to the workability question as expressed in a severability clause also makes the regulatory scheme more accountable to

44. Id. at 34,892 .

45. For a suggestion that the effect of certain "building blocks" might be "negative" without the others, see Anthony Paul, Dallas Burtraw, Karen Palmer \& Sophie Pan, The Future of the U.S. Power Sector: Implications of the Clean Power Plan, Presentation at the NYU Institute for Policy Integrity Forum (Oct. 28, 2014).

46. See Train v. Natural Res. Def. Council, Inc., 421 U.S. 60 (1975).

47. Matthew C. Stephenson \& Miri Pogoriler, Seminole Rock's Domain, 79 GeO. WASH. L. REV. 1449,1456 (2011).

48. Thomas W. Merrill \& Kristin E. Hickman, Chevron's Domain, 89 GEO. L.J. 833, 861-62 (2001).

49. See Motor Vehicles Mfrs. Ass'n of the U.S., Inc. v. State Farm Mut. Auto. Ins. Co., 463 U.S. 29, 43 (1983); Citizens To Preserve Overton Park, Inc. v. Volpe, 401 U.S. 402, 416 (1971); $c f$. Gans, supra note 35, at 643 (arguing that statutory severability often "enmesh[es] the judiciary in policy choices that are better left to the legislative branch"). 
the public. To understand the significance of democratic accountability in this context, one must realize that the severability decision imposes upon the public a regulatory scheme not approved in its exact form by the agency. It has long been a fundamental principle of administrative law that a reviewing court may not affirm an agency decision on a ground different from that adopted by the agency to justify its action. ${ }^{50}$ This principle, generally called the Chenery doctrine, reflects the fact that Congress has given the authority to make rules to the expert agency and not to the court. When the court affirms on a ground not adopted by the agency, it invades the proper province of the agency by substituting its judgment for the agency's. Severability raises similar issues. When a court upholds a portion of an administrative rule but sets aside others, the court leaves in place a regulatory scheme different from the scheme promulgated by the agency. And if the reviewing court sets aside the remainder, it creates a regulatory scheme (or perhaps deregulatory scheme) that the agency purposefully rejected by promulgating the rule.

These considerations do not lead us to the conclusion, which at least one scholar has reached, that severing a challenged provision of a rule constitutes unconstitutional judicial lawmaking..$^{51}$ Rather, they underscore the importance of allocating the workability question to the institution with the greater democratic pedigree. The workability question implicates compromises among constituents' interests - compromises that led to the creation of various regulatory objectives ultimately memorialized in the final rule. More direct lines of accountability to constituents provide agencies with a better understanding of these compromises and therefore with a better understanding of whether a regulatory remainder will adequately serve those regulatory objectives..$^{52}$

50. See SEC v. Chenery Corp. (Chenery II), 332 U.S. 194 (1947); SEC v. Chenery Corp. (Chenery $I), 318$ U.S. 80 (1943). As often happens in the law, the rationale for Chenery I was better explained when the Court reflected on its earlier decision in Chenery II than in the original decision itself.

57. In the context of statutes, Tom Campbell has argued that severance violates the Constitution's bicameralism-and-presentment requirements. In Campbell's view, just as the President and Congress cannot exercise line-item or one-house vetoes, so too the courts cannot leave in place laws that have not gone through Article I, Section 7's requirements for lawmaking. See Campbell, supra note 15, at 1503; see also Lars Noah, The Executive Line Item Veto and the Judicial Power To Sever: What's the Difference?, 56 WASH. \& LEE L. ReV. 235, 236-41 (1999) (mentioning this argument, but not asserting it); Laurence $\mathrm{H}$. Tribe, The Legislative Veto Decision: A Law by Any Other Name?, 21 HARV. J. ON LEGIS. 1, 22 (1984) (same). But see Dorsey, supra note 15 , at $885-89$ (showing that this view would undermine many provisions of the U.S. Code). We presume that Campbell would hold a similar view about administrative rules.

52. Cf. Stephenson \& Pogoriler, supra note 47 , at 1456-57 (discussing the supposed accountability benefits of Seminole Rock deference); John F. Manning, Constitutional Structure and Judicial Deference to Agency Interpretations of Agency Rules, 96 CoLUM. L. REV. 612, 629 (1996) 
Many scholars of administrative law have argued that agencies have more direct lines of accountability to the public than the courts. ${ }^{53}$ Agency procedural requirements for rulemaking are one line of accountability. When an agency disseminates a proposed rule, including one containing a severability clause, it must provide a "[g]eneral notice of proposed rule making" 54 and "give interested persons an opportunity to participate in the rule making through submission of written data, views, or arguments." 55

These procedural mechanisms for maintaining accountability between the public and the agencies can be significant to an agency's decision to promulgate a severability clause because the severability of regulatory provisions is often sufficiently important to induce stakeholders to comment formally. For example, in a comment on a proposed Fish and Wildlife Service (FWS) Rule, the Alaska Oil and Gas Association (AOGA) wrote:

Regardless of the form of the final rule, AOGA urges FWS to make a finding of severability. A severability finding would determine that the provisions of this rule, and the various applications of the rule, are distinct and severable from one another. . . A severability finding would ensure that if any provision or application of the $4(d)$ rule is stayed or invalidated, such a stay or invalidation will not affect other provisions or applications to other persons or circumstances. ${ }^{56}$

When the public does participate, agencies are required to respond to the public's comments in a reasoned fashion. ${ }^{57}$ Moreover, an agency's final rule

(same); Richard J. Pierce, Jr., Democratizing the Administrative State, 48 WM. \& MARY L. REv. $559,569-70$ (2006) (same). For a discussion of how deference to administrative severability clauses is similar to Seminole Rock deference, see infra notes 176-184 and accompanying text.

53. See, e.g., Stephen Breyer, Judicial Review of Questions of Law and Policy, 38 ADMIN. L. REV. 363 (1986); Elena Kagan, Presidential Administration, 114 HARv. L. Rev. 2245, 2373-74 (2001); Antonin Scalia, Judicial Deference to Administrative Interpretations of Law, 1989 DUKE L.J. 511; Cass R. Sunstein, Law and Administration After Chevron, 90 CoLUM. L. REv. 2071, 2086-87 (1990).

54. 5 U.S.C. $\$ 553$ (b) (2012).

55. Id. $\$ 553$ (c); see also Richard J. Pierce, Jr., Seven Ways To Deossify Agency Rulemaking, 47 ADMIN. L. REV. 59, 59 (1995) ("[R]ulemaking enhances fairness by allowing all potentially affected members of the public to participate in the decisionmaking process that determines rules that apply to their conduct[.]").

56. Letter from Marilyn Crockett, Exec. Dir., Alaska Oil \& Gas Ass'n, to U.S. Fish \& Wildlife Service 12 (July 14, 2008), http://www.regulations.gov/\#!documentDetail;D=FWS-R7-ES -2008-0027-0083 [http://perma.cc/D633-NH6D].

57. We note, however, that agencies have discretion to decide how to address comments. See Ctr. for Auto Safety v. Peck, 751 F.2d 1336, 1355 n.15 (D.C. Cir. 1985) ("An agency need not address every conceivable issue or alternative no matter how remote or insignificant."); 
must be a "logical outgrowth" of the agency's proposed rule, ${ }^{58}$ and the agency must address relevant and significant comments raised during the rulemaking in its statement of basis and purpose..$^{59}$ These notice-and-comment requirements serve to "reintroduce public participation and fairness to affected parties after governmental authority has been delegated to unrepresentative agencies. ${ }^{60}$ Notice-and-comment requirements thus give the public an opportunity to exercise accountability over an agency's decision to promulgate a severability clause.

Courts are less responsive to the wishes of the President and Congress than federal administrative agencies. ${ }^{61}$ The federal courts are subject to a variety of controls by the democratic branches, including control over the federal courts' budget and jurisdiction. But at the level of individual judges, the political branches have no official influence over the decisions of courts in particular cases. ${ }^{62}$ Of course, the President with the advice and consent of the Senate appoints individual judges. But once confirmed, federal judges enjoy lifetime appointments and undiminished pay, and they can be removed by the political branches only through the Constitution's onerous impeachment procedures. Indeed, part of the attraction of placing some decisions in the hands of federal judges is that they enjoy a great degree of removal from the whims and impulses of the political branches and of public opinion.

To be sure, one should not overestimate the democratic responsiveness of administrative agencies to the popular will. Unlike agency heads, career agency staff members are not subject to the political pressures imposed by Congress or the President. ${ }^{63}$ Many statutes also provide exemptions to participationenhancing notice-and-comment procedures. The Administrative Procedure Act (APA), which controls agency procedures when a more specific organic act

Reyblatt v. Nuclear Regulatory Comm'n, 105 F.3d 715, 722 (D.C. Cir. 1997) ("An agency need not address every comment, but it must respond in a reasoned manner to those that raise significant problems.").

58. See Int'l Union, United Mine Workers v. Mine Safety \& Health Admin., 626 F.3d 84, 94-95 (D.C. Cir. 2010).

59. See PPL Wallingford Energy LLC v. FERC, 419 F. 3 d 1194, 1198 (D.C. Cir. 2005).

60. Batterton v. Marshall, 648 F.2d 694, 703 (D.C. Cir. 1980); see also HENRY S. RichARDSON, Democratic Autonomy: Public Reasoning About the EndS OF Policy 219-20, 251 (2002) (asserting that notice-and-comment rulemaking is the most democratic form of administrative rulemaking).

61. For an account of how agencies can undermine accountability to the President, see generally Jennifer Nou, Agency Self-Insulation Under Presidential Review, 126 HARV. L. REV. 1755 (2013).

62. See generally John A. Ferejohn \& Larry D. Kramer, Independent Judges, Dependent Judiciary: Institutionalizing Judicial Restraint, 77 N.Y.U. L. REV. 962 (2002).

63. David J. Barron \& Elena Kagan, Chevron's Nondelegation Doctrine, 2001 SUP. CT. REV. 201, 242-43. 
does not, exempts an agency from undertaking notice and comment for rules regulating certain subject matters, such as foreign affairs, national security, and internal personnel matters. ${ }^{64}$ There are also exemptions if the rule is an interpretive rule or policy statement, or when the agency has good cause not to follow notice-and-comment requirements. ${ }^{65}$ Further, even when agencies do follow notice-and-comment procedures, these procedures are often more a means for ensuring favorable judicial review than they are a means of facilitating genuine public participation. ${ }^{66}$

But even if we cannot be uniformly sanguine about the power of formal procedural requirements to ensure genuine accountability and participation, we still maintain that agencies are also more responsive than the courts to representatives in the legislative and executive branches. ${ }^{67}$ The heads of executivebranch agencies are appointed and removable by the President. The heads of so-called "independent" agencies are also appointed by the President (though they can usually be removed only for cause), and the budgets of such agencies are prepared by the Office of Management and Budget. ${ }^{68}$

Agencies are also subject to oversight by Congress. They are subject to the budgetary control of congressional committees, and their heads frequently testify before Congress. As a result of these formal and other informal mechanisms of oversight, William Eskridge and Lauren Baer have argued that "agencies usually have institutionally superior access to the original expectations of the legislators .... [and] also have better knowledge than courts about current

64. See 5 U.S.C. $\$ \$ 552-556$ (2012).

65. Id.

66. See Barron \& Kagan, supra note 63, at 231-32; E. Donald Elliott, Re-Inventing Rulemaking, 41 DUKE L.J. 1490, 1490 (1992); Jody Freeman, Collaborative Governance in the Administrative State, 45 UCLA L. REv. 1, 12 (1997). But see Mariano-Florentino Cuéllar, Rethinking Regulatory Democracy, 57 ADMIN. L. Rev. 411, 463 (2005) ("Even though agencies have both the incentive and the opportunity to anticipate political reactions to their regulations, the notice and comment process is not treated as a charade. Agencies in these case studies often respond to comments by making substantive changes in their regulations. Their lawyers grapple with concerns raised by the commenters. At the same time, they change the proposed laws in response to feedback from interested parties.").

67. See Chevron, U.S.A., Inc. v. Natural Res. Def. Council, Inc., 467 U.S. 837, 865-66 (1984); Motor Vehicles Mfrs. Ass'n of the U.S., Inc. v. State Farm Mut. Auto. Ins. Co., 463 U.S. 29, 59 (1983) (Rehnquist, J., concurring in part and dissenting in part); Matthew D. Adler, Judicial Restraint in the Administrative State: Beyond the Countermajoritarian Difficulty, 145 U. PA. L. REV. 759, 875-76 (1997); Jerry L. Mashaw, Prodelegation: Why Administrators Should Make Political Decisions, 1 J.L. ECON. \& ORG. 81, 95-99 (1985).

68. See Neal Devins, Political Will and the Unitary Executive: What Makes an Independent Agency Independent?, 15 CARDozo L. REv. 273, 287-92 (1993) (discussing how the Department of Justice has affected legal decision making by the EEOC). 
congressional expectations." ${ }^{69}$ Further, some theorists posit that procedural requirements on regulation, such as notice-and-comment procedures, are means for Congress to intervene more easily when an agency is not adequately addressing the concerns of powerful constituencies. ${ }^{70}$

In short, the public and representatives in the executive and legislative branches maintain comparatively robust controls for holding agencies accountable in relation to the courts. Thus, when an agency opines on the workability of a regulatory remainder, it is in a better position than a court to know how the remainder will affect citizens and other entities.

\section{c. Rule of Law}

When a reviewing court defers to an administrative severability clause, it also promotes two important aspects of the rule of law: predictability and stability. ${ }^{71}$

Predictability benefits both agencies and regulated entities by encouraging efficient investment. ${ }^{72}$ When regulated entities evaluate which resources to invest in complying with the law most efficiently, an important consideration, especially for sophisticated actors, is how courts will treat recently promulgated administrative rules. If certain provisions of a rule are unlikely to survive judicial review, then entities may make different investment choices from the choices they would make if the provisions were likely to survive.

Similarly, greater predictability in the law allows agencies to determine how to use rulemaking resources most efficiently. Without severability, the probability that a court will set aside any particular provision is partly a function of the probability that a court will set aside any other provision in the same rule. Thus, the assessment of how best to regulate (for an agency) or how best to comply with the law (for regulated entities) is to some extent a function of how likely a court is to find potentially unlawful provisions severable. An agency's regulatory choices, for example, will depend on the probability it assigns to the possibility that a court will set aside certain provisions. If an agency is fairly

69. William N. Eskridge, Jr. \& Lauren E. Baer, The Continuum of Deference: Supreme Court Treatment of Agency Statutory Interpretations from Chevron to Hamdan, 96 GEO. L.J. 1083, 1176-77 (2008) (citations omitted); Eskridge, supra note 39, at 425-26.

70. Mathew D. McCubbins et al., The Political Origins of the Administrative Procedure Act, 15 J.L. ECON. \& ORG. 180 (1999).

7. See John FinNIS, Natural LaW and Natural Rights 270-76 (1980); LON L. Fuller, THE MORALITY OF LAW 37-52 (1969); JOSEPH RAZ, THE AUTHORITY OF LAW: ESSAYS ON LAW AND MORALITY 210-31 (2d ed. 2009).

72. Thomas W. Merrill, The Mead Doctrine: Rules and Standards, Meta-Rules and MetaStandards, 54 ADMIN. L. REV. 807, 822-23 (2002). 
certain that a court will defer to a severability clause, however, it may choose to promulgate a set of controversial regulations as a single rule rather than dispersing the regulations across several rules.

By adhering to a deference framework for administrative severability clauses, courts would mitigate some of the uncertainty in this probabilistic assessment. This point follows from the timing in which a severability clause appears in the interbranch dialogue. While a reviewing court can determine the workability of a regulatory remainder only after invalidating a challenged provision in litigation, an agency can use a severability clause to answer the workability question at the time the final rule is promulgated. So if federal courts deferred to severability clauses, the workability question would be one less element of possible uncertainty in the law.

Judicial deference to administrative severability clauses also promotes greater stability in regulatory schemes. A "remand-and-repromulgation cycle," as we call it, occurs when a regulation passes back and forth between an agency and the courts. If an agency could reliably influence how a reviewing court would make the severability decision by including a severability clause in a rule, then it could reduce the number of times it must re-promulgate a regulatory remainder that a court has erroneously invalidated. ${ }^{73}$

Reducing these cycles would save agencies and regulated entities costs caused by legal flux. ${ }^{74}$ Agencies would save scarce resources in two ways. Ex ante, an agency's drafting costs will be reduced because, assured in the knowledge that a severability clause will prevent the vacatur of an entire rulemaking, the agency will not have to engage in as rigorous of an assessment of the likelihood that each provision of a rule will be struck down. In this way, judicial deference to administrative severability clauses would partially offset some of the drawbacks associated with agency ossification. ${ }^{75}$ Ex post, agencies

73. Id. at 823 .

74. See Levin, supra note 16, at 300; Emily Hammond Meazell, Deference and Dialogue in Administrative Law, 111 Colum. L. REV. 1722, 1723 (2011); Daniel B. Rodriguez, Of Gift Horses and Great Expectations: Remands Without Vacatur in Administrative Law, 36 ARIz. ST. L.J. 599, 623 (2004). To be clear, we do not propose that courts consider these costs in individual cases because doing so would potentially violate the APA. See MD/DC/DE Broadcasters Ass'n v. FCC (MD/DC/DE Broadcasters II), 253 F.3d 732, 736 (D.C. Cir. 2001) (noting that the APA does not permit courts to consider the agency's costs in curing an invalid rule). However, courts should consider these costs when crafting judicial presumptions and rules of deference.

75. See, e.g., Thomas O. McGarity, Some Thoughts on "Deossifying" the Rulemaking Process, 41 DUKE L.J. 1385, 1385 (1992) [hereinafter McGarity, Some Thoughts]; Thomas O. McGarity, The Courts and the Ossification of Rulemaking: A Response to Professor Seidenfeld, 75 TEX. L. REV. 525, 528-36 (1997) [hereinafter McGarity, The Courts]; Mark Seidenfeld, Demystifying 
will save costs associated with re-promulgating rules already put through notice and comment. ${ }^{76}$ These costs are significant. One study, which one of the authors and Peter Schuck conducted in 1989 , concluded that post-remand proceedings at the agency level took an average of seventeen months to complete. ${ }^{\pi}$

True, to receive deference on its answer to the workability question, the agency must draft a severability clause and take it through notice and comment. This process involves non-negligible costs, especially when the regulatory scheme is highly technical or complex. The agency may also incur costs associated with litigation over the meaning and scope of the severability clause. ${ }^{78}$ But on average these costs pale in comparison to the average costs of redrafting a rule and taking it back through notice and comment.

Reducing the incidence of remand-and-repromulgation cycles would also save costs for regulated entities. A regulated entity, relying on an unchallenged portion of a rule and caught in such a cycle, must first adapt to the agency's rule, readapt to a regulatory vacuum after vacatur, and adapt for a third time to the original rule's valid provisions after the agency re-promulgates those provisions. ${ }^{79}$ But if a court's deference to an administrative severability clause prevented the court from erroneously invalidating the remainder, then the regulated entity would only need to adjust once.

Despite an administrative severability clause, there may be times when the remainder may turn out to be unworkable. This might occur, for example, when the agency does not correctly foresee what part of the rule might be struck down or how the regulatory remainder might function in the absence of the invalid portion. In these circumstances, a court's deference to the severability clause may entail additional costs for regulated entities. In particular, regulated entities relying on anchallenged portion of a rule will have to change their behavior when the agency first promulgates the rule and also when the agency changes the rule after deciding that the remainder is unworkable. How-

Deossification: Rethinking Recent Proposals To Modify Judicial Review of Notice and Comment Rulemaking, 75 TEX. L. REV. 483, 489-90 (1997).

76. See National Forest System Land Management Planning, 77 Fed. Reg. 21,162, 21,244 (Apr. 9 , 2012) (to be codified at 36 C.F.R. pt. 219) ("The Department retained the [severability] provision in the final rule, because rulemaking is an extensive Departmental and public undertaking, and the entire rule should not be dismissed if a court finds only a portion of the rule is inappropriate.").

7. See Peter H. Schuck \& E. Donald Elliott, To the Chevron Station: An Empirical Study of Federal Administrative Law, 1990 DUKE L.J. 984, 1050.

78. Cf. Adrian Vermeule, Introduction: Mead in the Trenches, 71 GEO. WASH. L. REv. 347, 350 (2003) (making a similar point about litigation over Chevron's domain); Merrill, supra note 72 , at 825 (same).

79. See Gans, supra note 35, at 653-54; Meazell, supra note 74, at 1723-24. 
ever, these occasions are likely to be rare for two reasons. First, the agency's expertise with respect to the workability question suggests that when the agency includes a severability clause, the remainder of the statute will be workable. Second, if agencies (and commenters) know that their judgments about severability are likely to carry dispositive weight with the courts in the future, they can be expected to devote more time and attention to these issues. This will lead to more accurate projections of workability. Together, these considerations suggest that the aggregate costs of correcting for ill-conceived severability clauses are still likely outweighed by the cost-savings of preventing remandand-repromulgation cycles.

Bearing in mind that courts currently do not defer to administrative severability clauses, one might also argue that there is a certain irony in advocating for change in the law as a way of making the law more stable. ${ }^{80}$ As the Supreme Court has explained in a different context, "[w]hat is of paramount importance is that Congress be able to legislate against a background of clear interpretive rules, so that it may know the effect of the language it adopts. " ${ }^{81}$ One might then think that courts should not change their treatment of administrative severability clauses because lawyers in the agencies should have a stable background against which to draft administrative rules.

If, however, an agency could reliably predict whether a court will defer to a severability clause, then the agency could reliably predict "the effect of the language it adopts." ${ }^{82}$ While changing the doctrine would disrupt the judicial background against which agencies currently regulate, the change would ultimately give the agencies more control over the consequences of their rules. We therefore advocate a change in the secondary rules of administrative law to make the primary rules more stable. ${ }^{83}$

\section{d. Efficiency}

Finally, if agency regulatory (or, for that matter, deregulatory) actions are generally socially beneficial, then judicial deference to the agency's answer to

80. See Nagle, supra note 11, at 245-46. See generally John F. Manning, Continuity and the Legislative Design, 79 NOTRE DAME L. ReV. 1863, 1864-65 (2004).

81. Finley v. United States, 490 U.S. 545,556 (1989).

82. Id.; see also Nagle, supra note 11 , at $245-46$ (providing several justifications for changing the test for severability).

83. See H.L.A. HART, THE CONCEPT OF LAW 80-81 (2d ed. 1994) (explaining the distinction between primary and secondary rules). 
the workability question promotes the development of efficient rules. ${ }^{84}$ When a court erroneously invalidates an entire rule that the agency would not itself rescind, society bears the costs associated with a "regulatory gap" (or, in the case of deregulation, a "regulatory glut") between invalidation and re-promulgation of the regulatory remainder. Moreover, this gap or glut may prove indefinitely long because agencies are sometimes able to promulgate a rule that they cannot, for political or fiscal reasons, later re-promulgate. ${ }^{85}$ For example, the interstate air pollution rules were upheld by the Supreme Court in EPA v. EME Homer City Generation, L.P. ${ }^{86}$ after almost a twenty-year delay stretching back over three presidential administrations to the 1998 NOx SIP call.

Another potential efficiency gain, which is more controversial, derives from the fact that judicial deference to administrative severability clauses promotes dynamic agency interpretations of statutes ${ }^{87}$ If courts would generally defer to administrative severability clauses, then a promulgating agency, knowing that a reviewing court is unlikely to vacate the entire rule, can more freely promulgate regulatory provisions that interpret statutes in new ways. As a consequence, the agency can more dynamically interpret statutes with rules containing a severability clause than rules without. ${ }^{88}$ The Clean Power Plan provides a good example of this phenomenon. Some experts doubt that a final rule based on the Clean Power Plan would be a valid exercise of the agency's delegated authority under the Clean Air Act. ${ }^{89}$ The EPA is aware of these criticisms, and one aspect of its strategy for dealing with them was to include the severability

84. See Levin, supra note 16 , at 298-99; Meazell, supra note 74 , at 1725 . We recognize that those who hold a view according to which the proper role of the administrative state is rather limited may disagree with the assumption in this sentence.

85. See McGarity, Some Thoughts, supra note 75 , at 1401.

86. 134 S. Ct. 1584 (2014).

87. See William N. ESKRIDGe, JR., Dynamic Statutory INTERPRETATION ch. 2 (1994) (explaining the inevitability of dynamic statutory interpretation).

88. A theoretical and empirical literature suggests that a similar adjustment in agency behavior occurred after the Court first announced the Chevron framework. See Linda Cohen \& Matthew Spitzer, Solving the Chevron Puzzle, 57 LAW \& CONTEMP. ProBs. 65, 67-68 (1994) (predicting that remand rates would equilibrate as agencies became more aggressive in their statutory interpretations); Schuck \& Elliott, supra note 77 , at 1043 (explaining that Chevron caused agencies to begin changing the grounds on which they based their decisions); Matthew C. Stephenson, The Strategic Substitution Effect: Textual Plausibility, Procedural Formality, and Judicial Review of Agency Statutory Interpretations, 120 HARV. L. REV. 528, 558 (2006).

89. See, e.g., Brian H. Potts \& David R. Zappo, EPA's Clean Power Play: Who Needs Congress?, 27 EleCtRICITY J. 26 (2014); Laurence H. Tribe, Op-Ed, The Clean Power Plan Is Unconstitutional, WALL ST. J., Dec. 29, 2014, http://www.wsj.com/articles/laurence-tribe-the-epas -clean-power-plan-is-unconstitutional-1419293203 [http://perma.cc/L8TA-3485]. 
clause, hoping that a reviewing court will defer to that clause if the court sets aside one or more of the four building blocks.

One potential rejoinder to the efficiency argument is that severability clauses make controversial rules more likely to be partially set aside, either because (1) expressing a position on the severability of a particular provision puts a target on the tenuous provision; or (2) courts are more willing to invalidate regulatory provisions when they need not invalidate the entire rule. On this view, even someone who thinks that agency actions generally conduce to the social good may thus conclude that an agency should not include a severability clause in a rule that is likely to be litigated because doing so makes a regulatory provision more likely to be set aside.

With respect to the first concern, we doubt that agency opinions on severability actually make legally suspect provisions of administrative rules significantly more likely to be challenged. Elite law firms scrutinize every rule that affects concentrated interests, either on the instructions of their existing clients or in the hope of attracting new ones. We doubt that there are many potentially problematic provisions that would be noticed only if the agency included a severability clause.

With respect to the second concern - that courts are more willing to set aside provisions contained in rules with a severability clause - we have two observations. First, the argument assumes that courts should leave in place a socially beneficial yet unlawful provision. One might disfavor unlawful regulatory provisions on principle, however, even if they are in fact socially beneficial. Second, even assuming that unlawful yet socially beneficial regulations are desirable, one must weigh the costs of relinquishing those regulations against the costs of erroneous vacatur of entire rules. Although it is impossible to quantify these social costs, we think the latter, even if less frequent, are likely to be greater in the aggregate.

To summarize the argument thus far, the severability decision involves two questions: (1) would the agency have intended the regulatory remainder to stay in effect in the absence of the challenged provision?; and (2) is the remainder lawful? We have argued that a promulgating agency, rather than a reviewing court, is best positioned to answer these questions. As the next Part explains, however, this is not the modern doctrine on administrative severability clauses. 
In fact, the D.C. Circuit has stated that severability clauses will rarely be dispositive of the severability decision. ${ }^{90}$

\section{THE STRANGE DEARTH OF ADMINISTRATIVE SEVERABILITY CLAUSES}

The previous Part argued for a particular allocation of decision-making authority on severability in administrative law: courts should defer to agencypromulgated severability clauses. For that division of labor to materialize, however, agencies must promulgate rules containing severability clauses, and courts must develop a framework for deferring to them.

In this Part, we turn our sights to judicial doctrine and administrative practice and show that neither condition obtains. In Part II.A, we focus on the courts. Federal judicial doctrine on administrative severability clauses is largely a re-application of the doctrine on statutory severability clauses to the administrative context. We briefly survey the doctrine on statutory severability clauses, explaining that it does not require courts to defer to severability clauses. We then show that this doctrine has been transmogrified into a doctrine of administrative law. In Part II.B, we show that administrative agencies rarely incorporate severability clauses into their rules. We posit that agencies usually do not consider including severability clauses in their rules because they do not receive a deference pay-off when they do. We conclude, therefore, that if courts want to capture the potential benefits of administrative severability clauses discussed in Part I, then they need to develop a framework for evaluating administrative severability clauses that would give these clauses some appreciable measure of deference.

\section{A. De Novo Review by the Courts}

Just as courts have applied the same test to determine the severability of both statutes and administrative rules, ${ }^{91}$ they have applied the same framework for evaluating the effect of severability clauses. This section therefore begins with a brief overview of the development of judicial doctrine on statutory severability clauses. ${ }^{92}$

90. See Cmty. for Creative Non-Violence v. Turner, 893 F.2d 1387, 1394 (D.C. Cir. 199o) (quoting United States v. Jackson, 390 U.S. 570,585 n.27 (1968)).

91. See supra Part I.A.

92. The historical discussion that follows owes much to outstanding earlier treatments in Klukowski, supra note 15, at 10-23; Nagle, supra note 11, at 210-18; and Shumsky, supra note 15, at 232-40. 
According to John Nagle, severability clauses began to appear in state and federal statutes in the late nineteenth century and had become common by $1910 .{ }^{93}$ Before the appearance of severability clauses, the federal courts had long presumed that partially unconstitutional statutes were severable, unless the provisions of the statutory remainder were so intertwined with the challenged provisions as to make the remainder unworkable. ${ }^{94}$

The U.S. Supreme Court first addressed the emerging phenomenon of statutory severability clauses in the 1914 Ohio Tax Cases. ${ }^{95}$ There, the Court accepted the statute's severability clause at face value. The Court, in leaving the remainder in place, assumed that the severability clause meant that the legislature intended for the statutory remainder to stay in effect. ${ }^{96}$

In the subsequent two decades, the Court moved further and further away from the literalist approach to severability clauses. In Hill $v$. Wallace, decided in 1922, the Court maintained that a severability clause expresses the legislature's intent for the remainder of a statute to stay in effect ${ }^{97}$ but declined to defer to the clause's plain meaning. ${ }^{98}$ The Court for the first time noted a basis on which a reviewing court might second-guess the plain meaning of a severability clause: to wit, the interconnectedness of the statute's provisions might demonstrate that the legislature would have intended for the court to strike the entire statute down, notwithstanding the severability clause. ${ }^{99}$ And in Dorchy $v$. Kansas, decided in 1924, the Court for the first time advised that a severability clause "provides a rule of construction which may sometimes aid in determining [legislative] intent. But it is an aid merely; not an inexorable command." 100

In 1928, the Court announced an even greater departure from a literal construction of severability clauses. In Williams $v$. Standard Oil Co., the Court confirmed that interconnectedness was a basis for doubting a severability clause's ostensible meaning and also added a second basis: a court could disregard a severability clause if there were "considerations which make evident" that "the

\footnotetext{
93. Nagle, supra note 11 , at 222.

94. See Allen v. Louisiana, 103 U.S. 80,84 (1880) (citing Warren v. Mayor \& Alderman of Charlestown, 68 Mass. (2 Gray) 84 (1854)).

95. 232 U.S. 576 (1914).

96. Id. at 594 .

97. Hill v. Wallace, 259 U.S. 44, 71 (1922) (noting that the severability clause "furnishes assurance to courts that they may properly sustain separate sections or provisions of a partly invalid act without hesitation or doubt as to whether they would have been adopted, even if the legislature had been advised of the invalidity of part").
}

98. Id. at 70 .

99. Id.

100. Dorchy v. Kansas, 264 U.S. 286, 290 (1924). 
legislature would not have been satisfied with what remains [after a court strikes down the challenged provision]."101 More significantly, the Court reversed the presumption in favor of severability for statutes that do not contain a severability clause. The Court held that a severability clause creates a presumption of severability, but the absence of such a clause creates a presumption "that the legislature intends an act to be effective as an entirety." 102

The early twentieth-century doctrine on severability clauses began to crystallize in Carter v. Carter Coal Co. ${ }^{103}$ According to Carter Coal, statutes are presumed inseverable. ${ }^{104} \mathrm{~A}$ severability clause creates a presumption of severability, but that presumption can "be overcome by considerations which establish 'the clear probability that . . . the Legislature would not have been satisfied with [the remainder]." ${ }^{105}$ Legislative intent determines whether "the provisions of a statute are so interwoven that[,] one being held invalid[,] the others must fall." ${ }^{106}$ Robert Stern offered the following synopsis of the law at the time: "Separability clauses are thus now significant only because of their absence. Like articles of clothing, if they are present little attention is paid to them, but if they are absent they may be missed." 107

Carter Coal's view of the significance of severability clauses largely persists, except that the Court no longer presumes that a statute is inseverable when a statute does not contain a severability clause. The leading modern case on statutory severability is Alaska Airlines. According to that widely cited case:

[W] hen Congress has explicitly provided for severance by including a severability clause in the statute[,] . . . the inclusion of such a clause creates a presumption that Congress did not intend the validity of the statute in question to depend on the validity of the constitutionally offensive provision.... [But] Congress' silence is just that-silence-and does not raise a presumption against severability. ${ }^{108}$

Alaska Airlines thus acknowledged that severability clauses create a presumption of severability, but it confirmed that statutes without a severability clause

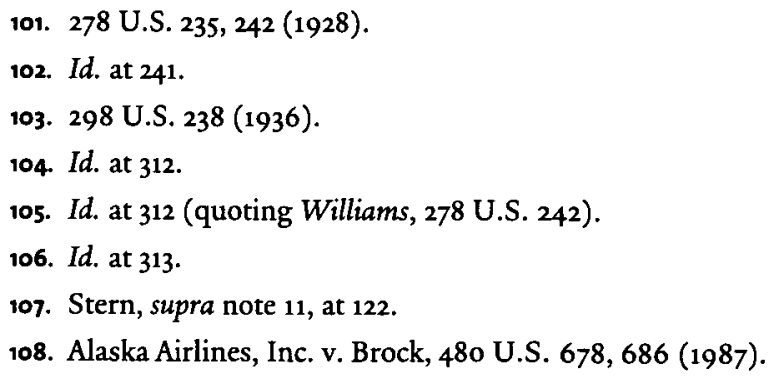


are not presumed inseverable. ${ }^{109}$ As noted earlier, Alaska Airlines also retained the two bases for finding a statute containing a severability clause nonetheless inseverable: "Unless it is evident that the Legislature would not have enacted those provisions which are within its power, independently of that which is not, the invalid part may be dropped if what is left is fully operative as a law."110

The Court has not clarified the strength of the presumption in favor of severability created by a severability clause, but the case law suggests that the presumption is rather weak. The Court has repeatedly said that "a severability clause is an 'aid merely; not an inexorable command""111 and that "whatever relevance such an explicit clause might have in creating a presumption of severability, . . . the ultimate determination of severability will rarely turn on the presence or absence of such a clause."112

The behavior of subsequent courts has borne out these observations. In several cases involving the severability decision, lower courts have ignored the existence of a severability clause. ${ }^{113}$ And in Buckley $\nu$. Valeo, the Court held the remainder of the Federal Election Campaign Act to be severable from its unconstitutional provisions without citing the Act's severability clause. ${ }^{114}$ Even when courts do not totally ignore a severability clause, the common trope is for

109. In Regan v. Time, Inc., 468 U.S. 641, 652-53 (1984), the plurality held that a presumption of severability exists even in the absence of a severability clause. But a majority of the Court has not adopted that holding. Scholars nonetheless disagree about whether the current Court presumes the severability of statutes not containing severability clauses. See Jona, supra note 15, at 704-05; Gillian E. Metzger, Facial Challenges and Federalism, 105 ColuM. L. REV. 873, 884 (2005); Shumsky, supra note 15, at 243. Compare Nat'l Fed'n of Indep. Bus. v. Sebelius, 132 S. Ct. 2566, 2668 (2012) (Scalia, J., dissenting) ("[W]hile the Court has sometimes applied at least a modest presumption in favor of . . . severability, it has not always done so." (citation and internal quotation marks omitted)); Klukowski, supra note 15, at 7-8 ("[C] ontrary to what some scholars argue - without a severability clause there is . . . a presumption [in favor of severability] only in the lower courts, not the Supreme Court."); and Nagle, supra note 11, at 220-21, with Dorf, supra note 15, at 313 ("[A]ll the states and the federal government have a general default principle authorizing courts to sever invalid provisions and applications from valid ones.").

110. Id. at 684 (quoting Buckley v. Valeo, 424 U.S. 1, 108 (1976) (per curiam)).

111. Reno v. Am. Civil Liberties Union, 521 U.S. 844, 884 n.49 (1997) (quoting Dorchy v. Kan., 264 U.S. 286, $290(1924))$.

112. United States v. Jackson, 390 U.S. 570,585 n.27 (1968); see also INS v. Chadha, 462 U.S. 919, 1014 (1983) (Rehnquist, J., dissenting).

113. Eubanks v. Wilkinson, 937 F.2d 1118, $1128-29$ (6th Cir. 1991) (discussing severability without noting the severability clause); Ragsdale v. Turnock, 841 F.2d 1358, 1377 (7th Cir. 1988) (Coffey, J., dissenting) (criticizing the majority for "completely disregard[ing] the statute's severability clauses as if they didn't exist").

114. 424 U.S. at 108-09. 
a federal court opinion dealing with statutory severability issues to begin with a rhetorical nod in the direction of a severability clause but then to analyze the severability decision as if the clause did not exist.

Several of the Court's recent decisions illustrate this treatment of severability clauses. In National Federation of Independent Businesses v. Sebelius (NFIB), both the majority opinion and Justice Ginsburg's separate opinion stated that the Court would follow Congress's explicit instruction that the Medicaid expansion be severed from the rest of the Act. ${ }^{115}$ However, the majority opinion then proceeded to determine - as if it were a totally separate inquiry - "what Congress would have intended in light of the Court's constitutional holding." 116

Consider also the Court's decision last Term in Executive Benefits Insurance Agency v. Arkison. ${ }^{117}$ In an earlier case, Stern v. Marshall, the Supreme Court considered the constitutionality of a particular provision of the Bankruptcy Code. Under section 157, bankruptcy courts may proceed to final judgment on certain "core" claims ${ }^{118}$ and may offer proposed findings of fact and conclusions of law on certain "non-core" claims. ${ }^{119}$ In Stern, the Court held that bankruptcy courts lack constitutional authority to enter final judgment on state-law counterclaims labeled as "core" under section ${ }_{157}$ (b). ${ }^{120}$ In Arkison, the Court considered whether Stern created a "gap" in the statute. According to the "gap" theory, bankruptcy courts lack constitutional authority to enter final judgment on certain core claims under Stern and lack statutory authority to make proposed findings of fact and conclusions of law as to those claims under section $157 .^{121}$ The Court noted that the statute contains a severability clause and held that the clause "closes the so-called 'gap."'122 However, as in $N F I B$, the Court then proceeded to analyze severability under the Alaska Airlines test as if the severability clause did not exist. ${ }^{123}$ The Court's reasoning in NFIB and Arkison

115. 132 S. Ct. 2566, 2607 (2012) ("We then follow Congress's explicit textual instruction to leave unaffected 'the remainder of the chapter, and the application of [the challenged] provision to other persons or circumstances."); id. at 2642 (Ginsburg, J., concurring in part, concurring in the judgment in part, and dissenting in part) ("In view of the Chief Justice's disposition, I agree with him that the Medicaid Act's severability clause determines the appropriate remedy.").

116. Id. at 2607 (quoting United States v. Booker, 543 U.S. 220, 246 (2005)).

117. 134 S. Ct. 2165 (2014).

118. 28 U.S.C. $\$ 157$ (b) (2012).

119. Id. at $\$ 157(\mathrm{c})$.

120. 131 S. Ct. 2594 (2011).

121. Arkison, 134 S. Ct. at 2172-73.

122. Id. at 2173 .

123. Id. 
shows that the presumption in favor of severability is weak. Indeed, if the Court took severability clauses at anything like face value, then those clauses would not so quickly be set to one side. Much of what Robert Stern said in 1937 continues to be true today: "if [severability clauses] are present[,] little attention is paid to them." ${ }^{124}$

We do not intend to criticize the courts' treatment of statutory severability clauses. Indeed, in Part III, we suggest that considerations of institutional competence may justify this treatment (though a full consideration of that issue is outside the scope of this Article). Rather, the point has been to set the stage for our discussion of administrative severability clauses. Earlier in the Article, we observed that the federal courts have, without much reflection, treated the severability of administrative regulations as not relevantly different from the severability of statutes. We noted that the Supreme Court's first and most substantial discussion of severability in administrative law contained no citations but simply repurposed the Alaska Airlines test for use in cases involving the severability of regulations. ${ }^{125}$ Similarly, after an extensive discussion of the statutory severability doctrine in Alliance for Community Media v. FCC, a panel of the D.C. Circuit wrote: "The [severability] analysis differs little in the context of invalidating provisions of regulations promulgated by an agency."126 Courts have thus assumed that the severability of statutes and of administrative regulations raise virtually identical considerations.

Unlike the case law on statutory severability clauses, the case law on administrative severability clauses is rather scarce. As the next section illustrates, the scarcity is due primarily to the fact that administrative agencies rarely include severability clauses in their rules. The cases that do exist, however, suggest that the federal courts also view administrative severability clauses as raising identical considerations to statutory severability clauses. Like severability clauses in statutes, administrative severability clauses create a "presumption" of severability. ${ }^{127}$ And as in the case of statutes, this presumption is largely unimportant under current jurisprudence. Indeed, borrowing from the Supreme Court's cases on statutory severability clauses, the D.C. Circuit in reviewing a Transit Authority regulation has stated that the "determination of severability

124. Stern, supra note 11 , at 122.

125. See supra Part I.A.

126. Alliance for Cmty. Media v. FCC, 10 F.3d 812, 830 (D.C. Cir. 1993), reh'g en banc granted, opinion vacated, 15 F.3d 186 (D.C. Cir. 1994), on reh'g, 56 F.3d 105 (D.C. Cir. 1995), affd in part, rev'd in part sub nom. Denver Area Educ. Telecomm. Consortium, Inc. v. FCC, 518 U.S. 727 (1996).

127. High Country Conservation Advocates v. U.S. Forest Serv., No. 13-CV-01723-RBJ, 2014 WL 4470427 , at ${ }_{4}$ (D. Colo. Sept. 11, 2014) ("I conclude that the severability clause creates a presumption that the North Fork Exception is severable ...."). 
will rarely turn on the presence or absence of [a severability clause]." ${ }^{128} \mathrm{We}$ conclude that the doctrine on administrative severability clauses, like the doctrine on statutory severability clauses, requires a reviewing court to recognize only a weak presumption in favor of severability and does not require the court to defer to an administrative severability clause.

The analysis in Part I suggested that regulatory schemes would benefit if courts deferred to administrative severability clauses. Accordingly, we think a reviewing court should adopt more than a weak presumption in favor of severability when the agency has chosen to include a severability clause in its rule. As we explain in the next section, the federal courts' treatment of administrative severability clauses has likely created a feedback loop between judicial doctrine and agency practice. Under the doctrine, courts do not defer to severability clauses, and this leads agencies to not promulgate these clauses-a consequence that in turn stunts the development of administrative severability doctrine.

\section{B. Neglect in the Agencies}

This Article began by inspecting the severability clause in the EPA's ambitious Clean Power Plan. Such clauses are rare. We have identified twenty-one agencies that included a severability clause in at least one of their rules between 2000 and 2014. ${ }^{129}$ Among these agencies, the Federal Trade Commission

128. Cmty. for Creative Non-Violence v. Turner, 893 F.2d 1387, 1394 (D.C. Cir. 1990) (quoting United States v. Jackson, 390 U.S. 570,585 n.27 (1968)); see also New York SMSA Ltd. P'ship v. Town of Clarkstown, 603 F. Supp. 2d 715, 734 (S.D.N.Y. 2009), affd 612 F.3d 97 (2d Cir. 2010) (internal quotation marks omitted) ("[T]he presence of [a severability] clause is not dispositive.").

129. They include: Bureau of Consumer Financial Protection, Bureau of Land Management, Chemical Safety and Hazard Investigation Board, Commodity Futures Trading Commission, Department of Health and Human Services, Department of Homeland Security, Department of Housing and Urban Development, Department of Justice, Employment and Training Administration, Environmental Protection Agency, Federal Communications Commission, Federal Railroad Administration, Federal Trade Commission, Forest Service, National Indian Gaming Commission, National Labor Relations Board, National Oceanic and Atmospheric Administration, National Park Service, Nuclear Regulatory Commission, Occupational Safety and Health Administration, and the Postal Service. To compile this list, we searched the Federal Register on Bloomberg Law for final rules containing either the word "severability" or the word "severable," and then checked the results manually to eliminate erroneous hits. Depending on how one counts agencies, one could conduct the same exercise and arrive at numbers slightly different from those described in the main text. For example, we decided to count the Food and Drug Administration, the Office of Population Affairs, and the Office of the Secretary of the Department of Health and Human Services as falling under HHS's umbrella. One could also reasonably count these as three separate agencies. Doing so would add two agencies to our total of agencies using severability clauses 
(FTC) generated the highest volume of severability clauses. From 2000 to 2014, the FTC promulgated 206 rules, thirteen $(6.3 \%)$ of which contained a severability clause. After the FTC, the next most active users of severability clauses from 2000 to 2014 were the EPA (with seven final rules containing a severability clause), followed by the Federal Communications Commission and the Forest Service (each with five) and the Federal Railroad Administration (with four). All other agencies have included severability clauses in their rules in three or fewer instances from 2000 to 2014. ${ }^{130}$ The normative significance of our data-for example, whether they support the claim that agencies include severability clauses in their rules too infrequently - is of course debatable. However, we think it is fair to conclude from the data that agencies infrequently include severability clauses in their rules.

Instead of including severability clauses in final rules, agencies tend to clarify their positions on severability only when required to do so in litigation - that is, they formulate a position on severability only after they become concerned that particular provisions of their rules are in jeopardy ${ }^{131}$ In conversation, supervising lawyers at several agencies indicated that severability was not a priority during notice and comment; rather, agency personnel assumed that they would consider severability only when it became an imminent issue in litigation. An informal survey of several former EPA General Counsels, including one of the co-authors, indicated that the topic of including a severability clause rarely came up, and when it did, agency general counsel staffs were often reluctant to imply that there was even a possibility that portions of their rule might be set aside. This attitude, while understandable, is myopic.

Waiting until litigation to opine on severability can have significant drawbacks. While severability clauses must be promulgated according to statuteprescribed procedural formalities - most commonly, notice-and-comment procedures - positions developed in litigation do not require such procedures. In-

and would reduce the concentration of severability clauses in a single agency's rules. Our basic point that agencies rarely include severability clauses is not affected by how one individuates related agencies.

130. See infra Appendix for more detail.

131. Nat'l Ass'n of Mfrs. v. NLRB, 717 F.3d 947, 963 (D.C. Cir. 2013) (asking for reconsideration of severability in petition for rehearing); MD/DC/DE Broadcasters Ass'n v. FCC, 253 F.3d 732 (D.C. Cir. 2001) (same); Virginia v. EPA, 116 F.3d 499, 500-o1 (D.C. Cir. 1997) (same); Davis Cnty. Solid Waste Mgmt. v. EPA (Davis County II), 108 F.3d 1454, 1455 (D.C. Cir. 1997) (same); Davis Cnty. Solid Waste Mgmt. v. EPA, 101 F.3d 1395, 1411 (D.C. Cir. 1996) (Davis County I) (opining on severability at oral argument); Akiachak Native Cmty. v. Jewell, 995 F. Supp. 2d 1, 6 (D.D.C. 2013) (articulating an agency's position on severability in a legal brief); Principal and Response Brief of Appellees/Cross-Appellants at 59-64, Nat'l Ass'n of Mfrs., 717 F.3d 947 (No. 12-5068 \& 12-5138) (discussing the NLRB's severability argument). 
deed, trial and appellate briefs are typically confidential until the time they are filed, and they are often reviewed only by a handful of agency lawyers. As a consequence of these procedural differences, severability arguments raised in litigation do not benefit regulatory regimes along the dimensions discussed in Part I-expertise, accountability, the rule of law, and efficiency - at least not to the same extent as severability clauses.

Severability opinions expressed through briefs are less likely to reflect the agency's subject-matter expertise. Agency staff with advanced training in scientific and economic analysis, for example, will often review legislative rules, but not review legal briefs. The benefits of review by agency staff became particularly evident in Davis County I and II. In Davis County I, operators of several existing municipal solid waste (MSW) combustor units challenged EPA's 1995 MSW combustion standards. The court held that the 1995 standards, as applied to small MSW combustors, exceeded EPA's statutory authority under section 129 of the Clean Air Act. ${ }^{132}$ On the advice of the EPA's counsel at oral argument, the court vacated the entire rule rather than severing the ultra vires provision. ${ }^{133}$ In Davis County II, however, the EPA petitioned for rehearing on the severability issue, conceding that the agency's counsel had not fully grasped the workability of the regulatory provisions that would remain after the court's ruling. ${ }^{134}$ The Court of Appeals reinstated the standards except as applied to small MSW combustors and cement kilns. ${ }^{135}$ This was a close call for the agency and presumably for communities that are affected by pollution from MSW combustors. Had the agency's position on severability been expressed through a severability clause, rather than through a lawyer at oral argument, the agency's administrative expertise could have been brought more directly to bear on the severability question confronting the court.

An administrative severability clause is also a more accountable and participatory way for an agency to express its opinion on severability than a litigation brief. As noted, to include a severability clause in a legislative rule pursuant to the APA, an agency must provide a " $[\mathrm{g}]$ eneral notice of proposed rulemaking," ${ }^{136}$ give "interested persons an opportunity to participate in the rule making" by submitting comments, ${ }^{137}$ and address significant comments in its statement of basis and purpose. ${ }^{138}$ By contrast, for reasons of legal strategy, po-

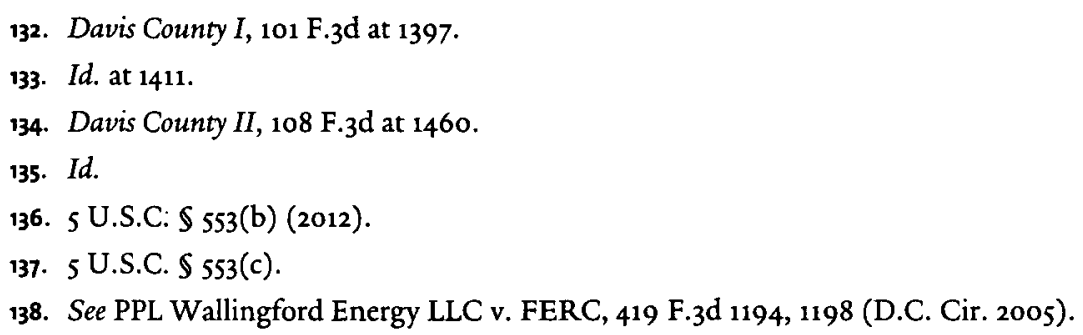


sitions developed in litigation almost never involve participation by the public; at most, a few litigants aligned with the agency may be consulted.

Severability clauses can also make regulatory schemes more predictable and stable than positions on severability developed in litigation, due to the greater prospectivity and formality of severability clauses. A severability clause in a rule will always be promulgated far in advance of a legal brief opining on severability. Therefore, a rule with a severability clause creates reliance interests that adjust for the possibility that some of the rule's provisions may be invalidated and severed from the rest. By contrast, an agency develops a position on severability in litigation only after regulated entities have begun to plan their affairs around a rule's substantive provisions. Similarly, procedural requirements for promulgating severability clauses make regulatory schemes more stable at the margins because these requirements must be satisfied in order to rescind these clauses once they are in effect. ${ }^{139}$ Consequently, one expects fewer changes in an agency's position on severability when the change is announced through a severability clause rather than in a legal brief.

In light of the potential drawbacks of waiting until litigation to develop a position on severability, why do agencies choose to wait rather than include a severability clause in the text of a rule? While more research needs to be done on this question, ${ }^{10}$ one way to approach it is to compare an agency's decision whether to include a severability clause in a rule with the choice between interpreting a federal statute using a legislative rule or using an informal agency action.

Under Chevron, an agency interpreting a federal statute can choose either to pay now or pay later. ${ }^{141}$ The agency can "purchase" Chevron deference for its

139. See Nat'I Family Planning \& Reproductive Health Assoc. v. Sullivan, 979 F.2d 227 (D.C. Cir. 1992) (holding that a reversal of a prior agency action requires at least the extent of procedural formality initially used in adopting the action).

140. We think it would be worthwhile to survey agencies' legislative counsels to determine why agencies choose to include or not to include a severability clause in a rule. This research would be a piece of the larger project of investigating the process of regulating "from the inside," similar to recent work that has begun to shed light on the process of legislative drafting in Congress. See Lisa Schultz Bressman \& Abbe R. Gluck, Statutory Interpretation from the Inside-An Empirical Study of Congressional Drafting, Delegation and the Canons: Part II, 66 STAN. L. ReV. 725 (2014) [hereinafter Bressman \& Gluck, Part II]; Abbe R. Gluck \& Lisa Schultz Bressman, Statutory Interpretation from the Inside-An Empirical Study of Congressional Drafting, Delegation, and the Canons: Part I, 65 STAN. L. REV. 901 (2013) [hereinafter Gluck \& Bressman, Part I]; Victoria F. Nourse \& Jane S. Schacter, The Politics of Legislative Drafting: A Congressional Case Study, 77 N.Y.U. L. REV. 575 (2002). A recent article by Christopher Walker takes the first step in this larger project. See Christopher J. Walker, Inside Agency Interpretation, 67 STAN. L. REV. 999 (2015).

141. See Lisa Schultz Bressman, Beyond Accountability: Arbitrariness and Legitimacy in the Administrative State, 78 N.Y.U. L. REV. 461, 539 (2003); Elliott, supra note 66, at 1491; Merrill, supra 
interpretation by investing agency resources in costly notice-and-comment procedures. If the agency does so, then its reward is less judicial scrutiny. Alternatively, the agency can choose not to invest in formal procedures. But if it does so, the agency might later have to "purchase" judicial approval through stronger interpretive arguments evaluated under the less deferential Skidmore framework.

The courts' doctrine on administrative severability clauses, however, does not share Chevron/Skidmore's incentive structure. Promulgating a severability clause through notice-and-comment procedures can be costly. It may entail significant ex ante costs associated with investigating and reflecting on the various regimes that might result from an enforceable severability clause. Furthermore, the agency may believe that a severability clause entails higher expected ex post costs. For example, an agency may be concerned that a severability clause will make weaknesses in its regulatory program easier to detect. Or an agency may think that a severability clause will weaken its position in litigation, either because a court may wonder why the agency included a severability clause if the agency believed that the regulatory program was lawful ${ }^{142}$ or because the court may feel it easier to partially invalidate a rule that contains a severability clause. ${ }^{143}$

Under current judicial doctrine, the agency receives little payoff for incurring these ex ante and ex post costs. As explained in the previous section, courts tend not to give substantial deference to severability clauses, preferring instead to conduct the same severability analysis that they would perform in the absence of a severability clause. This lack of deference may often be the de-

note 72 , at 822 ; Merrill \& Hickman, supra note 48 , at 887 ; Stephenson, supra note 88 , at $547^{-}$ 48; Cass R. Sunstein, Chevron Step Zero, 92 VA. L. REV. 187, 225-26 (2006).

142. Applications for FDA Approval To Market a New Drug: Patent Submission and Listing Requirements and Application of 30-Month Stays on Approval of Abbreviated New Drug Applications Certifying that a Patent Claiming a Drug Is Invalid or Will Not Be Infringed, 21 C.F.R. $\$ 314$ (2014) ("From the comments we have received to the proposed rule, we believe there is a possibility that we will be challenged on various portions of the final rule. We expect we will prevail in any such challenge, as the final rule and each of its provisions is legally sound. If, however, a court should conclude that any one or more provisions of the final rule is invalid, we wish to emphasize our intent that the remaining provisions of the final rule be permitted to take effect." (emphasis added)).

143. Cf. The Supreme Court Decision in INS v. Chadha and Its Implications for Congressional Oversight and Agency Rulemaking: Hearings Before the Subcomm. on Admin. Law \& Governmental Relations of the H. Comm. on the Judiciary, 98th Cong. 275 (1983) (statement of Rep. John Joseph Moakley) ("[Including severability clauses in legislation] has not been an intelligent policy [because those clauses] are a dangerously open invitation to the courts to assume th[e] legislative function."); Kameny, supra note 15, at 1001 (arguing that some inseverability clauses serve "an in terrorem function, as the legislature attempts to guard against judicial review altogether by making the price of invalidation too great"). 
cisive factor for an agency considering whether to include a severability clause in a rule. For example, the National Indian Gaming Commission responded to a comment requesting that it include a severability clause in one of its rules as follows:

The Commission ... addressed [the suggestion that the Commission include a severability clause in its rule] in the previous preamble, stating that severability clauses are not conclusive of an agency's intent and that "the ultimate determination of severability will rarely turn on the presence or absence of such a clause." 144

Thus, an agency considering whether to include a severability clause in a rule may conclude that the potential benefits are not worth the candle. The absence of a deference framework specifically for administrative severability clauses is a critical feature of a vicious cycle in which courts do not defer to severability clauses, so agencies do not include them, so courts have no occasion to reconsider whether they should defer to them.

Our aim here is not to suggest that agencies should include a severability clause in every rule. Even if rulemaking were costless, including a severability clause in a rule would not be advisable under some circumstances. First, severability is not advisable when the rule's efficacy depends on the interconnectedness of its provisions. ${ }^{145}$ Second, a severability clause might prove to be misguided if the agency does not know whether it would want a court to sever a challenged provision. ${ }^{146}$ Third, there may be some provisions that are severable and others that are not, and it may be difficult to predict which combinations should result in severability. Finally, although a regulatory remainder left standing may be preferable to the court's invalidation of the entire rule, the

144. 25 C.F.R. $\ 543$ (2014) (citing Canterbury Liquors v. Sullivan, 999 F. Supp. 144 (D. Mass. 1994)).

145. See 5o C.F.R. $\$ 17$ (2014) ("We recognize that severability clauses are frequently used in legislation but have decided that such a clause would not be useful in the current rule. The rule is organized in a manner that reflects the connection among the different paragraphs while also indicating the distinctiveness of the different provisions. We would expect a court to take the distinctiveness of the various provisions into consideration during any judicial review of the rule.").

146. Promoting Wholesale Competition Through Open Access Non-Discriminatory Transmission Services by Public Utilities: Recovery of Stranded Costs by Public Utilities and Transmitting Utilities, 62 Fed. Reg. 12,274, 12,281 (1997) (codified at 18 C.F.R. \$35) ("The Commission will not, at this time, make any determination whether or not [certain regulatory provisions] are severable ... . Circumstances at the time of any court order would dictate how we should proceed and we would consider all such circumstances, and the entirety of our policy decisions, before determining how to respond to a court decision."). 
benefits of that regulatory remainder will not always outweigh the drafting costs of promulgating a severability clause.

Our point here is that the current doctrine on administrative severability clauses does not give agencies adequate incentives to include these clauses in their rules even though these clauses can often benefit regulatory schemes more than agency positions on severability developed in litigation. As we have explained, even if courts adopt our proposal by developing a deference framework for administrative severability clauses, an agency will sometimes have good reasons for not including a severability clause in a rule. However, a framework for severability clauses would ensure that agencies will be compensated for their upfront investment in drafting severability clauses and would thereby expand an agency's options for creating the best regulatory scheme with its scarce resources.

\section{DEFERENCE TO ADMINISTRATIVE SEVERABILITY CLAUSES}

This Part proposes a deference framework for severability clauses. Before introducing that framework, we first debunk the primary argument against judicial deference to administrative severability clauses - namely, that severability clauses are not the best evidence of the agency's intent regarding severability. We then explain the framework that courts should follow when reviewing an administrative severability clause.

\section{A. Disassociating Statutory and Administrative Severability Clauses}

Part I demonstrated that regulatory schemes containing severability clauses would benefit in several important ways if courts deferred to an agency's opinion on the intent and workability questions expressed in a severability clause. Part II, however, showed that courts tend not to defer to severability clauses. Rather, courts typically give a rhetorical nod to the existence of a severability clause but then conduct their own de novo review of agency intent and workability. This doctrinal treatment of administrative severability clauses is symptomatic of the federal courts' tendency to treat severability analysis in administrative law as substantially the same as severability analysis for statutes. The key, then, to understanding why courts hardly defer to administrative severability clauses is to understand their treatment of statutory severability clauses.

Severability clauses ordinarily state in plain terms that Congress intends for a court to sever an unconstitutional provision from a statute's remainder. Federal courts typically regard clear statutory text as strong evidence of Congress's 
intent. ${ }^{147}$ Why then do courts look past the plain text of a severability clause to analyze severability de novo? The accepted explanation is that statutory severability clauses are boilerplate provisions. ${ }^{148}$ We have not seen this argument systematically developed, but it might proceed in the following way: severability clauses are not reliable evidence of Congress's intent because they are generally added to statutes without much (or any) consideration by members of Congress or their staffs. Therefore, a reviewing court is justified in looking past a severability clause because Congress was likely much more concerned with the statute's substantive provisions than with the severability clause.

We hear the ring of truth in the claim that Congress is institutionally illequipped to have an informed view of the workability of severability clauses. In particular, several features of the legislative process in Congress (which we describe below) justify a court's scrutiny of a statutory severability clause's apparent meaning. If the rulemaking process within the administrative agencies shared these features, then the parallel treatment of statutory and administrative severability clauses might be justified. However, in several important ways, the rulemaking process is substantially different from the process of drafting statutes. Indeed, the reasons for thinking that Congress lacks capacity and incentive to consider the severability of statutes are, interestingly, reasons to

147. See, e.g., NFIB v. Sebelius, 132 S. Ct. 2566,2583 (2012) (“[T] intent is the statutory text."); Chamber of Commerce v. Whiting, 131 S. Ct. 1968, 1977 (2011) ("When a federal law contains an express preemption clause, we focus on the plain wording of the clause" because it is "the best evidence of Congress' preemptive intent."); West Virginia Univ. Hosp., Inc. v. Casey, 499 U.S. 83, 98 (1991) ("The best evidence of [Congress's] purpose is the statutory text adopted by both Houses of Congress and submitted to the President.").

148. See Trainor v. Hernandez, 431 U.S. 434, 463 (1977) (Stevens, J., dissenting) (mentioning "a legitimate severability clause, or some other equally innocuous provision"); Lindenberg $v$. First Fed. Sav. \& Loan Ass'n, 90 F.R.D. 255, 258 (N.D. Ga. 1981) (describing a severability clause as "merely boilerplate"); H.R. REP. No. 988-91, at 49 (1970) (describing a severability clause as "the usual separability provision in legislation"); 140 CONG. REC. H3117 (daily ed. May 5, 1994) (statement of Rep. Slaughter) (arguing that floor debate on the inclusion of a severability clause was unnecessary); 134 CONG. REC. 12,280 (1988) (statement of Rep. Frank) (describing a severability clause as "just boilerplate severability"); 2 SUTHERLAND STATUTES AND STATUTORY CONSTRUCTION $\$ 44.08$ (5th ed. 1992); 2 NORMAN J. Singer, STATUTES AND STATUTORY CONSTRUCTION $\$ 44.8$, at 585 (6th ed. 2001); Israel E. Friedman, Inseverability Clauses in Statutes, 64 U. CHI. L. REV. 903, 903 (1997) ("In part because severability clauses have become boilerplate, these clauses have had little effect on courts making severability determinations."); Kameny, supra note 15, at 1005; Max Radin, A Short Way with Statutes, 56 HARV. L. REV. 388, 419 (1942) ("Are we really to imagine that the legislature had, as it says it has, weighed each paragraph literally and come to the conclusion that it would have enacted that paragraph if all the rest of the statute were invalid? That contradicts the ordinary experience of which every citizen takes notice."); Stern, supra note 11, at 122; Tribe, supra note 51, at 22 (mentioning "a boilerplate severability clause (of the sort most laws contain)"). 
think that agencies have such capacity and incentive. We consider three such reasons below.

\section{Attention Paid to Severability Clauses}

Some commentators have argued that members of Congress and their staff do not pay much attention to severability clauses. Instead, legislative counsel throw them "unthinkingly . . . into a statute without considering whether [they] really want[] each provision of [their] handiwork to stand independently." 149 Because Congress uses severability clauses so "indiscriminately," a reviewing court could reasonably conclude that, if taken literally, severability clauses would "cover situations which they were never intended to reach."

The process by which administrative agencies decide to include severability clauses in rules, however, is vastly different from this supposed congressional process. Agencies do not just throw severability clauses into their regulations. As we explained in Part II.B, even the most active user of severability clausesthe FTC-has included a severability clause in only $6.3 \%$ of its rules from 2000 to 2014. ${ }^{151}$ Moreover, unlike Congress, agencies may not include severability clauses in their rules unthinkingly because the APA's rulemaking procedures require agencies to respond to public input about their rules. To be sure, congressional committees do hold regular hearings on proposed legislation that would in theory permit the public to provide input about severability clauses. Administrative agencies, however, are required to respond in a rational way to public comments; otherwise, their rules can be set aside as arbitrary and capricious. ${ }^{152}$ Moreover, our research suggests that agencies tend to respond with care to comments suggesting the inclusion or removal of severability clauses. For example, in response to one set of comments, the Fish and Wildlife Service explained: "We recognize that severability clauses are frequently used in legislation but have decided that such a clause would not be useful in the current rule." ${ }^{153}$ Similarly, in the statement of basis and purpose for one of its rules, the National Indian Gaming Commission wrote:

149. Nagle, supra note 11 , at 239.

150. Stern, supra note 11, at 124 .

151. See supra notes 129-130 and accompanying text.

152. See Reyblatt v. Nuclear Regulatory Comm'n, 105 F.3d 715, 722 (D.C. Cir. 1997) ("An agency need not address every comment, but it must respond in a reasoned manner to those that raise significant problems.").

153. Special Rule for the Polar Bear, 73 Fed. Reg. 76,249, 76,267 (Dec. 16, 2008) (to be codified at 50 C.F.R. pt. 17). 
[S]ome commenters advocated for the inclusion of a severability clause .... [T] he Commission declines to include a severability clause in this regulation because it believes that the regulations are not so intertwined that striking one provision would necessarily always require invalidation of the entire part, and the lack of a severability clause will not compel a court's finding on the issue. ${ }^{154}$

In short, there is no evidence that administrative agencies throw severability clauses unreflectively into their rules.

\section{Time Pressure}

Even if members of Congress and their staffs were inclined to reflect on the manifold potential ramifications of a statutory severability clause, they often lack the time to do so. Congressional staffs work under tremendous time pressure, making it less likely that they will have had the opportunity to consider the implications of a complex, probabilistic, and procedural instrument like a severability clause. ${ }^{155}$ Nourse and Schacter's study of legislative drafting in Congress indirectly supports this hypothesis by finding that:

Several staff members complained about the dangers of drafting bills on the floor, as this increased the risks of the process becoming "ugly," haphazard, and driven by political imperative. Staffers expressed concern about last-minute drafting without a lot of public scrutiny. Specific fears included provisions being "slipped in," people losing track of whether one provision squares with another, or a provision being added to satisfy the needs of a senator in trouble for re-election. ${ }^{156}$

Similarly, in Gluck and Bressman's more recent study of congressional legislative staff, respondents reported that time pressures often made it impossible to comply with their goal of making the usage of terms consistent across a statute. ${ }^{157}$ Neither Nourse and Schacter nor Gluck and Bressman surveyed staffers on their use of severability clauses, but we suspect that time pressures also in-

154. Minimum Internal Control Standards for National Indian Gaming Commission, 77 Fed. Reg. 58,708, 58,709 (Sept. 21, 2012) (to be codified at 25 C.F.R. pt. 543).

155. Cf. Cuéllar, supra note 66, at 420 n.31 (noting that Congress's ability to control administrative agencies "is almost certainly shaped by the legislature's scarce resources and their competing uses. Legislators must vote on foreign policy, campaign among their constituencies, evaluate tax law changes, and supervise staff. . . . [T] hey must develop techniques for deploying scarce attention and resources.").

156. Nourse \& Schacter, supra note 140, at 592-93 (footnote omitted).

157. See Gluck \& Bressman, Part I, supra note 140, at 936. 
hibit staffers from meaningfully considering these clauses' potential ramifications.

It is true that agencies labor under their own time pressures. ${ }^{158}$ Congress can impose deadlines on agency action, ${ }^{159}$ the public can petition agencies to initiate rulemaking, ${ }^{160}$ and, like Congress, agencies are not immune from the pressures of election cycles. Still, various statutory and executive controls require agencies to take care in promulgating rules. As noted, the APA, certain agency organic acts, and various other statutes impose procedural requirements on rulemaking that require deliberation and reasoned responses to comments by a promulgating agency. Review by OIRA typically requires agencies to justify major proposed rulemakings on the basis of sophisticated economic analysis. These various procedural mechanisms require an agency to be careful about each aspect of a proposed rule. ${ }^{161}$ Indeed, much of the literature on agency ossification maintains that many of these controls on agency action require agencies to use scarce resources inefficiently in order to explain their reasons for promulgating rules. ${ }^{162} \mathrm{We}$ think it is fair to conclude that agencies promulgate rules in a more deliberate and deliberative way than Congress enacts stacutes, which in part suggests that there should be less concern about deference to administrative severability clauses than about deference to statutory severability clauses.

158. See generally Cass R. Sunstein \& Adrian Vermeule, The Law of "Not Now": When Agencies Defer Decisions, 103 U. PA. L. REV. 157 (2014); Jacob E. Gersen \& Anne Joseph O'Connell, Deadlines in Administrative Law, 156 U. PA. L. REV. 923 (2008).

159. See, e.g., In re Bluewater Network, 234 F.3d 1305, 1316 (D.C. Cir. 2000) (compelling agency rulemaking in light of "a clear statutory mandate, a deadline nine-years ignored, and an agency that had admitted its continuing recalcitrance").

160. See Mass. v. EPA, 549 U.S. 497, 527 (2007).

161. Studies suggest that the average time between several agencies' notices of proposed rulemaking and the promulgation of their final rules is somewhere between one-and-a-half and five years - far longer than the time between election cycles that Congress has to pass major legislation. See Stephen M. Johnson, Ossification's Demise? An Empirical Analysis of EPA Rulemaking from 2001-2005, 38 ENVTL. L. 767, 770 (2008) (finding that, between 2001 and 2005, the EPA took an average of between 1.5 and 2 years to finalize a rule after publishing it); Cornelius M. Kerwin \& Scott R. Furlong, Time and Rulemaking: An Empirical Test of Theory, 2 J. PUB. ADMIN. RES. \& THEORY 113, 134 (1992) (finding that the EPA took an average time of 1,108 days to promulgate a rule); McGarity, Some Thoughts, supra note 75, at 1388 (noting that "OSHA health standards rarely take less than five years to promulgate").

162. Freeman, supra note 66, at 9; William S. Jordan, III, Ossification Revisited: Does Arbitrary and Capricious Review Significantly Interfere with Agency Ability To Achieve Regulatory Goals Through Informal Rulemaking?, 94 Nw. U. L. REV. 393 (2000); Pierce, supra note 54; Seidenfeld, supra note 75, at 514; Mark Seidenfeld, Hard Look Review in a World of TechnoBureaucratic Decisionmaking: A Reply to Professor McGarity, 75 TeX. L. Rev. 559 (1997); Paul R. Verkuil, Comment, Rulemaking Ossification-A Modest Proposal, 47 ADMIN. L. REV. 453 (1995). 


\section{Centralization}

The Nourse-Schacter and Gluck-Bressman surveys have shed light on the variability, complexity, and polycentricity of statutory drafting in Congress. Statutes are regularly the result of many legislative bargains and are drafted by multiple committees over multiple iterations. In their study of staffers on the Senate Judiciary Committee, for example, Nourse and Schacter found broad consensus on the proposition that " $[\mathrm{t}]$ he [legislative] drafting process . . . is better understood as multiple drafting processes, varying along many axes," 163 reinforcing the aphorism that Congress is a "they," not an "it." 164 Nourse and Schacter continue:

$[\mathrm{R}]$ esponsibility for drafting a bill often is diffused among many people and groups, chief among them staffers from different offices, Legislative Counsel drafters, and lobbyists. This dispersal of responsibility makes it problematic for a court to try to isolate any single moment, actor, or event that decisively conferred meaning on a contested provision. $^{165}$

Moreover, respondents in Gluck and Bressman's study emphasized that committees often operate as drafting "islands," unconnected from the business of the other committees. ${ }^{166}$

The messy reality of the statutory drafting process has several implications for the plausibility of ascribing to Congress a specific intention to draft and pass workable severability clauses. First, the committee drafting model creates incentives for individual members to include severability clauses in statutes; members want to ensure that the portions of bills they have drafted will remain in effect even if portions drafted by members of other committees eventually fail. The larger and more complex a bill, the more likely it contains an unconstitutional provision, and thus the stronger the incentive to include a severability clause. The practice of legislating by means of omnibus bills strengthens incentives to include severability clauses, but not always in situations in which they would be advisable. Second, the isolation of congressional committees suggests that blanket severability clauses may be inserted into portions of bills drafted by one committee that were not intended to apply to other portions of the bill. This suggests that a statutory severability clause, drafted and passed by

\footnotetext{
163. Nourse \& Schacter, supra note 140 , at 583 .

164. See Kenneth A. Shepsle, Congress Is a "They," Not an "It": Legislative Intent as Oxymoron, 12 INT'L REV. L. \& ECON. 239, 239 (1992).

165. Nourse \& Schacter, supra note 140 , at 618.

166. Gluck \& Bressman, Part I, supra note 140 , at 936.
} 
a committee without reference to other parts of the bill, does not provide an informed opinion on the larger body's intent or on the workability of the statutory remainder. Third, traditional forms of democratic accountability likely do not chasten the temptation to include a far-reaching severability clause in a statute merely to protect a limited set of provisions. In Congress, responsibility for a severability clause gone wrong would be diffused across all members, diminishing any particular member's concerns that she will be held unaccountable for inserting an ill-advised severability clause into a statute. This point also suggests that these clauses do not contain an informed opinion on the statutory remainder's workability. In short, Congress arguably has too many cooks in the kitchen for a severability clause meaningfully to reflect the legislative will.

Not so for the administrative agencies. Instead of multiple committees working in multiple drafting stages, agencies draft rules in a more concerted fashion. ${ }^{167}$ There is no such thing as a "Christmas tree" rule. ${ }^{168}$ Rules are typically drafted by a single team of drafters, representing different offices, whose draft work product is reviewed multiple times - at least in general terms, if not word by word - by agency general counsels and often by the agency head or her deputies. Agency proposed rules are also subject to OIRA review, which puts them through a rigorous economic analysis. Furthermore, the temptation to include a severability clause in a rule in the hope of preserving important substantive provisions is reduced by the fact that responsibility for an unworkable regulatory remainder will fall squarely upon the agency (or, more realistically, the agency head). Thus, administrative severability clauses are more likely than statutory severability clauses to reflect the actual intent of their drafters.

Regardless of the merits of arguments discrediting statutory severability clauses, the case for not deferring to administrative severability clauses is based on an inapt analogy between the agencies and Congress. Having made the case that courts should defer to administrative severability clauses in Part I.B and having debunked the analogy between legislative and administrative severability clauses in this section, we next lay out a deference framework for administrative severability clauses.

167. The distinction between the drafting methods used in Congress and those used in agencies might not be as stark in the context of negotiated rulemaking (so-called "neg reg"). However, even in the case of negotiated rulemaking, agencies are less likely than Congress to endorse a severability clause that covers aspects of a rule or statute that it was not meant to cover.

168. Cf. Nat'l Fed'n of Indep. Bus. v. Sebelius, 132 S. Ct. 2566, 2675 (Scalia, J., dissenting) (discussing "Christmas tree" bills). 


\section{B. A Chevron-Style Framework for Severability Clauses}

We propose a two-step deference framework for administrative severability clauses, similar in some respects to Chevron deference. The Chevron framework addresses how a federal court should treat an agency's interpretation of a federal statute that it administers. The framework proceeds in two steps. At Step One, the court asks whether "the intent of Congress is clear" after employing traditional canons of statutory construction; if so, "that is the end of the matter ... the court ... must give effect to the unambiguously expressed intent of Congress." ${ }^{169}$ Step One launches a purely legal inquiry. Employing interpretive techniques in which they are skilled, courts ask whether the agency has stepped beyond the boundaries of its statutory authority. If, after employing these techniques, a reviewing court determines that the statute is silent or ambiguous on the relevant issue, then the court proceeds to Step Two. At Step Two, the court again undertakes a purely legal inquiry and asks whether the agency's interpretation is "based on a permissible construction of the statute." then the court defers to the agency's interpretation because "a court may not substitute its own construction of a statutory provision for a reasonable interpretation made by the administrator of an agency." ${ }^{171}$

Chevron acknowledges that within a certain "zone of reasonableness"172 statutory interpretation is closer to creating policy than it is to discerning legal norms, and that it is better to allow the more expert and accountable agency to create policy. As the Supreme Court explained in 2005:

In Chevron, this Court held that ambiguities in statutes within an agency's jurisdiction to administer are delegations of authority to the agency to fill the statutory gap in reasonable fashion. Filling these gaps, the Court explained, involves difficult policy choices that agencies are better equipped to make than courts. If a statute is ambiguous, and if the implementing agency's construction is reasonable, Chevron requires a federal court to accept the agency's construction of the statute, even if the agency's reading differs from what the court believes is the best statutory interpretation. ${ }^{173}$

169. Chevron, U.S.A., Inc. v. Natural Res. Def. Council, Inc., 467 U.S. 837, 842-43 (1984).

170. Id. at 843 .

17. Id. at 844 .

172. RiCHARD A. POSNER, HOW JUDGeS THINK 86-87 (2008) (explaining the meaning of the phrase "zone of reasonableness").

173. Nat'l Cable \& Telecom. Ass'n v. Brand X Internet Servs., 545 U.S. 967, 980 (2005) (emphasis added). 
Thus, both courts and agencies have roles to play under Chevron-roles delimited by their institutional capacities. Using traditional interpretation methods, courts police the clear statutory boundaries, while agencies, employing their own expertise, may create reasonable policies within those boundaries.

The deference framework for administrative severability clauses that we propose is similar. At Step One, a reviewing court should determine whether the regulatory remainder is lawful. Michael Dorf has called this the "taint problem" for severability analysis because the remainder of a statute or rule may be "tainted" by residual legal defects when a court invalidates a certain provision. ${ }^{174}$ This inquiry is analytically prior to the two questions of the Alaska Airlines severability test.

If the remainder is lawful, then at Step Two a court should determine what the severability clause requires and defer to it. Like Chevron Step Two, the courts' review at this stage should be highly deferential because, as we explained in Part I.B, agencies are better than courts at determining when a regulatory remainder will be workable. ${ }^{175}$ Like Chevron, our deference framework assigns to the courts and agencies roles delimited by each institution's capacities.

The deference framework we propose would break the vicious cycle in which courts, rather than agencies, make the severability decision. By giving agencies deference at Step Two, it would (1) allow agencies to answer the intent and workability questions and (2) provide agencies with incentives to include severability clauses in more rules when appropriate.

Before expounding further upon the mechanics of our proposed deference framework, we should note that administrative law already has the conceptual resources to implement the framework. Under the Seminole Rock doctrine, ${ }^{176}$ which predates Chevron by nearly forty years, federal courts give what is essen-

174. Dorf, supra note 15 , at 307,310 .

175. With one potential exception, the Supreme Court has never invalidated an agency's construction of a statute at Chevron Step Two. See Lisa Schultz Bressman, Schechter Poultry at the Millennium: A Delegation Doctrine for the Administrative State, 109 YALE L.J. 1399, 1399$1400 \&$ n.5 (2000) (citing AT\&T Corp. v. Iowa Utilities Bd., 119 S. Ct. 721, 734-36 (1999), as a potential exception). Lower federal courts have behaved similarly, though, as expected, there have been more decisions decided against the agency at Step Two than there have been in the Supreme Court. See Orin S. Kerr, Shedding Light on Chevron: An Empirical Study of the Chevron Doctrine in the U.S. Courts of Appeals, 15 YALE J. ON REG. 1, 30-31 (1998) (noting that, in the years 1995 and 1996 , U.S. courts of appeals upheld agency interpretations at Step Two in one hundred cases and rejected them in twelve).

176. See Bowles v. Seminole Rock \& Sand Co., 325 U.S. 410, 414 (1945) (“[T] he ultimate criterion [in interpreting a regulation] is the administrative interpretation, which becomes of controlling weight unless it is plainly erroneous or inconsistent with the regulation."); see also Auer v. Robbins, 519 U.S. 452, 461 (1997) (providing the modern formulation of the doctrine). 
tially Chevron deference to an agency's interpretation of its own rules. ${ }^{17}$ Like Chevron, the contemporary statement of the Seminole Rock doctrine involves a two-step analysis. First, a reviewing court asks whether the agency's interpretation steps outside the boundaries established by the agency's original rulethat is, whether the agency's interpretation is "inconsistent" with the regulation. ${ }^{178}$ If not, the court asks whether the agency's interpretation is "plainly erroneous." ${ }^{179}$

Two rationales support the doctrine. First, an originalist rationale ${ }^{180}$ posits that agencies, as the drafters of administrative rules, have special insight into their intent when promulgating those rules. ${ }^{181}$ Second, a functionalist rationale emphasizes the agencies' specialized expertise in administering their "'complex and highly technical regulatory program [s]."'182

Seminole Rock is related to severability because questions of severability are fundamentally questions of interpretation. ${ }^{183}$ Just as archetypal questions of statutory interpretation oblige the court to examine the legislative authorities (for example, text, structure, and legislative history) to determine the legislature's intent, so too does severability analysis oblige the court to examine the regulation in search of the agency's intent. If severability is fundamentally a question of interpretation, then an agency's opinion on the severability of its rule is an interpretation of that rule deserving Seminole Rock deference. Small wonder, then, that the rationales underlying the Seminole Rock doctrine dovetail with the two questions of the Alaska Airlines test. The "touchstone" of severability analysis is the lawmakers' intent. And since agencies have special insight into their intent when enacting administrative rules, they are best

17. See Decker v. Nw. Envtl. Def. Ctr., 133 S. Ct. 1326, 1339 (2013) (Scalia, J., concurring in part and dissenting in part).

178. Auer, 519 U.S. at 461 (quoting Robertson v. Methow Valley Citizens Council, 490 U.S. 332, $359(1989))$.

179. Id.

180. See Stephenson \& Pogoriler, supra note 47 , at 1454.

181. See Martin v. Occupational Safety \& Health Review Comm'n, 499 U.S. 144, 152 (1991); Bruh v. Bessemer Venture Partners III, 464 F.3d 202, 208 (2d Cir. 2006); Manning, supra note 52, at 630-31; Stephenson \& Pogoriler, supra note 47 , at 1454.

182. Thomas Jefferson Univ. v. Shalala, 512 U.S. 504, 512 (1994) (quoting Pauley v. BethEnergy Mines, Inc., 501 U.S. 680, 697 (1991)); see also Amerada Hess Pipeline Corp. v. FERC, 117 F.3d 596, 604 (D.C. Cir. 1997) (according deference "because the Commission has greater technical expertise in this field than does the Court"); Stephenson \& Pogoriler, supra note 47 , at 1456 .

183. See Michael C. Dorf, Facial Challenges to State and Federal Statutes, 46 STAN. L. REV. 235, 289 (1994); Edward A. Hartnett, Modest Hope for a Modest Roberts Court: Deference, Facial Challenges, and the Comparative Competence of Courts, 59 SMU L. Rev. 1735, 1752 (2006); Metzger, supra note 109, at 928; Nagle, supra note 11, at 232-33; Stern, supra note 11, at 115 . 
equipped to opine on that intent. Further, severability analysis requires a determination of whether the remainder of a regulation is workable. Since agencies have special expertise in the "complex and highly technical regulatory program [s]" they administer, they are best equipped to opine on the workability of regulatory remainders. ${ }^{184}$ Thus, although neither the Supreme Court nor the D.C. Circuit have applied the Seminole Rock doctrine to administrative severability clauses, accommodating the deference framework we propose would not require a seismic shift in the current doctrine. We now discuss each step of our proposed deference framework in more detail.

\section{Step One: Address Legal Defects}

At Severability Step One, a reviewing court must determine whether the regulatory remainder is lawful or "tainted" by residual legal defects. ${ }^{185}$ The Alaska Airlines severability test does not require this inquiry, largely because the Alaska Airlines test assumes that the reviewing court will not leave in place a remainder that is unlawful. In any case, a reviewing court has a duty to determine whether the regulatory remainder is lawful.

The proper scope of a court's review for residual legal defects will inherently be somewhat open-ended. On one hand, a court may not leave in place legal defects that are apparent from its review of the provision challenged in litigation. On the other hand, the duty to determine the existence of residual defects does not require the court to comb the entire rule in search of problems. Indeed, such a requirement would, in some cases, be far too onerous for a court to perform and would arguably violate the Constitution's case-or-controversy jurisdictional requirement by giving a court license to rule on the legality of any aspect of a rule, even if not challenged by the parties. ${ }^{186}$ Thus, a reviewing court is obliged to determine whether the remainder contains residual legal defects that are substantially related to the challenged provision. We now explain how a court should undertake that task.

184. It may seem awkward to think of clauses contained in rules as interpretations of those same rules. But upon reflection, there is nothing mysterious about parts of a text explaining how to interpret other parts of a text. The definitions at the beginning of almost every federal statute, for example, do just that. See Nicholas Quinn Rosenkranz, Federal Rules of Statutory Interpretation, 115 HARV. L. REV. 2085, 2104 (2002). Of course, interpretive clauses will themselves require interpretation, but this form of regress is entirely benign; nothing sets it apart from any other piece of ordinary language. Any interpretation of ordinary language will itself require an interpretation, which will in turn require an interpretation, and so on. See Larry Alexander \& Frederick Schauer, On Extrajudicial Constitutional Interpretation, 110 HARV. L. REV. 1359, 1369-70 (1997).

185. Dorf, supra note 15 , at 310-26.

186. U.S. CONST, art III, $\ 2$. 


\section{a. Identifying Defects}

A reviewing court considering whether to leave a regulatory remainder in place must determine whether the remainder suffers from any of several types of legal defects, including whether the remainder is unconstitutional, ultra vires, or arbitrary and capricious. ${ }^{187}$

First, a regulatory remainder may be unconstitutional. Suppose the Department of Homeland Security promulgates a rule containing a severability clause and two substantive provisions: first, the rule bans all "First Amendment activities" in domestic commercial airports, and second, the rule contains a fallback provision stating that, "In the event that a court sets this rule aside, all expressive activities that, consistent with the First Amendment, can be banned in an airport, shall be banned." ${ }^{188}$ If a plaintiff challenges the first provision in court, the remainder clearly would contain a residual constitutional defect. While the reviewing court would set the first provision aside as unconstitutionally overbroad, ${ }^{189}$ the remainder would be unconstitutionally vague. ${ }^{190}$

Second, a regulatory remainder may also be ultra vires, even if the original rule was not. Suppose a federal statute directs the Federal Reserve Board to promulgate two types of regulations. ${ }^{191}$ First, the Board must establish procedures to be used in an administrative hearing to determine whether a particular financial institution that does not fall under the statutory definition of a "bank" nevertheless offers many of the services that banks offer (banking services). Second, after those procedures are established, the Board must promulgate regulations to monitor and control the activities of institutions found to offer banking services to ensure that consumers are adequately protected. Now suppose the Board promulgates a rule that establishes both the procedures to be used in hearings and the substantive regulations governing institutions that offer banking services. Finally, suppose the hearing procedures are unconstitutional. In this example, if a plaintiff successfully challenges the hearing procedures,

187. We considered whether a court's ground for invalidating a regulatory provision should affect the degree of deference that the court gives to a severability clause, but we concluded that it should not. Regulatory provisions are either valid or invalid. If they are valid, they remain valid irrespective of the type of legal defect from which juxtaposed regulatory provisions might suffer.

188. This illustration is based on an example offered by Dorf, supra note 15, at 312 . Dorf's example itself is based on Board of Airport Commissioners v. Jews for Jesus, Inc., 482 U.S. 569, 570-71 (1987).

189. Jews for Jesus, 482 U.S. at 570-71.

19o. Dorf, supra note 15 , at 312 .

191. The following example is loosely based on Board of Governors of the Federal Reserve System $v$. Dimension Financial Corp., 474 U.S. 361 (1986). 
the regulatory remainder would suffer from a residual ultra vires defect because the statute directs the Board to promulgate substantive regulations only after promulgating procedures to be used in hearings.

Finally, the regulatory remainder might be legally defective because it is arbitrary and capricious. This defect is most common when a reviewing court renders the remainder inconsistent with the rule's statement of basis and purpose. ${ }^{192}$ To illustrate, consider the D.C. Circuit's decision in $M D / D C / D E$ Broadcasters Association II. ${ }^{193}$ In $M D / D C / D E$ Broadcasters $I$, the court considered the constitutionality of an FCC rule regarding the equal employment opportunity policies of broadcasters. ${ }^{194}$ To ensure that minority and women candidates knew about available job opportunities with broadcast stations, the FCC rule required broadcasters that sought licenses from the FCC to make "a good faith effort to disseminate widely any information about job openings." ${ }^{195}$ To "afford[] broadcasters flexibility in designing their EEO programs," the rule allowed broadcasters to select one of two options for accomplishing that goal. ${ }^{196}$ Under Option A, licensees had to "undertake four approved recruitment initiatives in each two-year period." 197 The FCC did not require licensees who selected Option A to report the race and gender of job applicants. ${ }^{198} \mathrm{Un}$ der Option B, licensees could design their own outreach programs but had to report the race and gender of each job applicant and how the applicant was referred to the station. ${ }^{199}$ The D.C. Circuit held that Option B required racebased discrimination and was accordingly subject to strict scrutiny. ${ }^{200}$ The court then held that Option B was unconstitutional because it was not narrowly tailored to any ostensibly compelling interest that the Commission might

192. For the purpose of determining whether a rule is arbitrary and capricious, courts are obliged to consider an agency's reasoning only at the time the agency made its decision. See SEC v. Chenery Corp. (Chenery I), 318 U.S. 80, 87-88 (1943).

193. $\mathrm{MD} / \mathrm{DC} / \mathrm{DE}$ Broadcasters Ass'n v. FCC (MD/DC/DE Broadcasters II), 253 F.3d 732 (D.C. Cir. 2001).

194. MD/DC/DE Broadcasters Ass'n v. FCC (MD/DC/DE Broadcasters $I), 236$ F.3d 13, 16 (D.C. Cir. 2001).

195. Id. at 17 (citing Review of the Commission's Broadcast Equal Employment Opportunity Rules and Policies, 15 FCC Rec. 2329, 2364 (2000)).

196. Id.

197. Id.

198. Id. (citing 47 C.F.R. $\$ 73.2080$ (d) (2014)).

199. Id.

200. Id. at 20-21. 
have had. ${ }^{201}$ Finally, the court found that the unconstitutional provision was inseverable from the remainder of the rule and set aside the entire rule. ${ }^{202}$

In its petition for rehearing in $M D / D C / D E$ Broadcasters Association $I I$, the FCC asked the court to reinstate the remainder of its rule. ${ }^{203}$ Writing for the court, Judge Douglas Ginsburg observed that the FCC had two goals in promulgating the rule, but that Options $A$ and $B$ would each achieve only one of those goals. ${ }^{204}$ As the court observed, the FCC's statement of basis and purpose stated "that Option A could satisfy the goal of achieving broad outreach" and "that Option B was added in order to afford broadcasters flexibility." 205 The court accordingly concluded that severing the invalid part of the rule "would leave in force a rule that, in view of the Commission's own stated goals, would be arbitrary and capricious" ${ }^{206}$ because the remainder would achieve only one of the stated goals. The majority plainly thought they had confronted a taint problem. After setting aside the unconstitutional part of the FCC's rule, the rule's remainder became, in the majority's view, arbitrary and capricious. Thus, the court set aside the entire rule.

In dissent, Judge David Tatel criticized the majority for not deferring to the agency's litigation position. He maintained that the court should defer to the agency's opinion on severability because the agency had the statutory authority to promulgate Option A and expressed its position in the briefs that Option B was severable. ${ }^{207}$ Regardless of whether the regulatory remainder was arbitrary and capricious under the case's facts, we agree with the majority's endorsement of the following principle: a court may not leave in place a regulatory remainder that is inadequately supported by the original rule's statement of basis and purpose. ${ }^{208}$ While courts should defer to an agency's opinion whether a rule's remainder will be workable (a claim we defended in Part I), courts should not defer to the agency's position on whether the rule's statement of basis and purpose adequately supports the remainder. An agency's statement of basis and

\footnotetext{
201. Id. at 21-22.

202. Id. at 22-23.

203. MD/DC/DE Broadcasters Ass'n v. FCC (MD/DC/DE Broadcasters II), 253 F.3d 732, 736 (D.C. Cir. 2001).

204. Id.

205. Id. at 735 .

206. Id. at 736 .

207. Id. at 739-41. On this point, the dissent may have had the better argument. The majority observed that in promulgating the rule, the Commission had two goals: broad outreach and flexibility. See id. at 735. But as the dissent noted, the remainder of the rule - that is, Option A-itself gave the broadcasters a great deal of flexibility because the broadcasters could choose between thirteen different programs under Option A. See id. at 741.
}

208. See 5 U.S.C. $\$ 706(2)(A)(2012)$. 
purpose need not persuade the reviewing court that the regulatory remainder is a good idea; indeed, from the court's perspective the remainder may seem like a disaster. However, for the court to satisfy its obligations under the APA, it must be persuaded that the regulatory remainder has adequate support in the agency's statement of basis and purpose - that is, that the agency has provided reasons for the regulatory provisions that remain.

Residual arbitrary and capricious review accommodates the sensible idea that the larger the portion of an administrative rule that a court invalidates, the less willing a court should be to enforce the remainder. Generally speaking, for example, the larger the portion of a rule that a court invalidates, the more likely that the remainder will also be set aside because it is more likely to be arbitrary and capricious under the rule's statement of basis and purpose. We do not advocate that courts use the extent of invalidation as a factor when determining whether to sever invalid provisions of rules, but the extent of invalidation may be helpful in predicting what a court will do with a regulatory remainder.

\section{b. Remedying Defects}

When a reviewing court identifies residual legal defects in a rule containing a severability clause, it should first determine whether it could invalidate the remaining infirmities without causing additional taint problems. If invalidating additional provisions would remove the residual defects, then the court should generally use its equitable discretion to invalidate those additional provisions and uphold the remainder.

But if the court cannot eventually rid the remainder of taint problems, then the remedy should depend on the type of legal defect tainting the remainder. Consider the three types of legal defects discussed above. Neither courts nor agencies can fix rules that are ultra vires or constitutional. In our hypothetical example of the Federal Reserve Board's banking regulations, neither the reviewing court nor the Board can change the fact that the remainder of the Board's rule is ultra vires in the absence of pre-established administrative procedures for determining whether a financial institution offers banking services. The same is true for constitutional violations. Thus, if a rule inextricably violates an agency's congressional mandate or the Constitution, the court should invalidate the entire rule.

By contrast, courts should often use the remand-without-vacatur remedy when a court finds a regulatory remainder to be arbitrary or capricious. Ordinarily, courts "set aside" unlawful agency actions by vacating them, which nul- 
lifies the action and requires the agency to initiate new procedures. ${ }^{209}$ Courts sometimes, however, remand the rule without vacating it, ${ }^{210}$ which leaves a rule in force while the agency works to cure its defects. ${ }^{211}$ Remand without vacatur eliminates some of the costs of the remand-and-repromulgation cycle because regulated entities do not have to adjust to a regulatory vacuum during the time that the agency works to fix its original rule's defects. Of course, if the agency does not eventually revise a remanded rule to the court's satisfaction, then the court will vacate the rule in its entirety. But while the rule is on remand, regulated entities must still comply with the regulatory remainder. ${ }^{212}$

Remand without vacatur will often be the appropriate remedy for a rule containing a severability clause whose remainder is arbitrary or capricious. Courts have typically used remand without vacatur in two sets of circumstances: where the court determines (1) that the agency can likely cure a rule's defects and (2) that vacatur would have disruptive consequences for a regulatory regime. ${ }^{213}$ With respect to the first circumstance, the promulgating agency can

209. See Checkosky v. SEC, 23 F.3d 452, 465 (D.C. Cir. 1994) (Silberman, J., concurring) (“[Vacatur] requir[es] the agency to initiate another rulemaking proceeding if it would seek to confront the problem anew." (citation omitted)).

210. See Stephanie J. Tatham, The Unusual Remedy of Remand Without Vacatur, ADMIN. CONF. U.S. 54-58 (Jan. 3, 2014), http://www.acus.gov/sites/default/files/documents /Remand\%20Without\%20Vacatur\%2oFinal\%2oReport.pdf [http://perma.cc/Y778-TY99] (collecting seventy-three cases employing remand without vacatur between 1972 and 2013).

211. Remand without vacatur is somewhat controversial in the D.C. Circuit. The Circuit seemed firmly to approve the practice in Checkosky, 23 F.3d at 465 , but members of the court continue to claim that it is illegal. See, e.g., Milk Train, Inc. v. Veneman, 310 F.3d 747, 758 (D.C. Cir. 2002) (Sentelle, J., dissenting) ("Although I greatly respect the majority's attempt to save a well-intended relief program from possibly inefficient further proceedings, I do not think we can lawfully do so."); Checkosky, 23 F.3d at 490-91 (Randolph, J., dissenting) (arguing that remand without vacatur is prohibited by $\$ 706(2)(A)$ of the APA, which provides that a reviewing court "shall" set aside unlawful agency action). See generally Levin, supra note 16, at 361 (arguing that remand without vacatur strikes a balance between agency discretion and judicial activism); Daniel B. Rodriguez, Of Gift Horses and Great Expectations: Remands Without Vacatur in Administrative Law, 36 ARIZ. ST. L.J. 599, 601 (2004) (arguing that courts should use remand without vacatur only sparingly because the remedy encourages courts to exercise sweeping review of agency actions). The Administrative Conference of the United States has approved remand without vacatur as a legitimate remedy under 5 U.S.C. $\$ 706(2)$, and has recommended that courts consider the remedy as an alternative to vacatur. See Administrative Conference Recommendation 2013-6: Remand Without Vacatur, ADMIN. CONF. U.S. (Dec. 5, 2013), http://www.acus.gov/sites/default/files/documents /Remand\%2oWithout\%20Vacatur\%20_\%20Final\%20Recommendation.pdf [https://perma .cc/ $/$ BBM-MDBF].

212. Tatham, supra note 210 , at 1.

213. See Allied-Signal, Inc. v. Nuclear Regulatory Comm'n, 988 F.2d 146, 151-52 (D.C. Cir. 1993); Levin, supra note 16 , at 380 . 
usually fix a regulatory remainder containing a severability clause that a court finds arbitrary and capricious by providing additional reasons for the remainder in the rule's statement of basis and purpose. With respect to the second circumstance, because agencies do not frequently include severability clauses in their rules, when an agency does so, this provides strong circumstantial evidence that the agency believes that vacatur would have disruptive consequences for its regulatory scheme.

One D.C. Circuit opinion has already suggested this approach to severability. In Alliance for Community Media, a panel of the D.C. Circuit held that FCC regulations authorizing cable providers to ban indecent material on cable access channels violated the First Amendment. ${ }^{214}$ Consequently, the court had to determine whether to sever the unconstitutional provisions of the FCC's rule from the regulatory remainder. The court observed that, were it to sever the invalid provisions, it would leave in place a regulatory scheme under which indecent material could be regulated only on cable channels for unaffiliated commercial programmers but not on cable channels set aside for public, educational, or governmental use. ${ }^{215}$ The FCC, however, had not provided a justification for this seemingly odd distinction between cable access channels. Accordingly, the court was concerned that leaving this scheme in place would be arbitrary and capricious. Rather than invalidate the entire rule, the court remanded it without vacatur. ${ }^{216}$ The court explained:

[W] here an agency is involved, a court need not strike down a regulation to effect a reconsideration by the issuing body. Thus, a court will issue a remand to the issuing agency if there is "substantial doubt" as to whether the agency intended its regulation to be severable. Such a remand is often in the best interest of justice in that it allows the agency to reconsider the residue of its original regulation and keeps judges out of the business of administrators. ${ }^{217}$

However, Alliance for Community Media was later vacated, ${ }^{218}$ and no subsequent cases have followed its approach of ordering remand without vacatur in these circumstances. We agree, however, with Alliance's approach.

214. Alliance for Cmty. Media v. FCC, 10 F.3d 812, 829 (D.C. Cir. 1993).

215. Id.

216. Id. at 831 .

217. Alliance for Cmty. Media, 10 F.3d at 830 (citation omitted).

218. See Alliance for Cmty. Media v. FCC, 15 F.3d 186 (D.C. Cir. 1994) (granting rehearing en banc and vacating 10 F.3d 812); Alliance for Cmty. Media v. FCC, 56 F.3d 105 (D.C. Cir. 1995) (determining en banc that the FCC regulations were constitutional and thus did not require remand or vacatur). 
The foregoing discussion explains how courts should proceed at Severability Step One. A court should determine (1) whether invalidating a portion of a rule creates residual legal defects for the regulatory remainder that are substantially related to the challenged provision and (2) whether these defects can be removed. If the defects are inextricable, then the appropriate remedy will depend on the nature of the defect. When the defect is constitutional or ultra vires in nature, the court should set aside the entire rule. But when an inextricable defect renders the rule arbitrary and capricious, the court should generally remand the rule without vacating it. If, on the other hand, the regulatory remainder does not contain inextricable legal defects, the reviewing court should proceed to Severability Step Two, to which we now turn.

\section{Step Two: Defer to the Agency}

Part I.B showed that if courts deferred to administrative severability clauses, then regulatory schemes would promote expertise, accountability, the rule of law, and efficiency. In light of these potential benefits, we maintain that a court's review at Severability Step Two should be highly deferential and relatively straightforward: determine what the severability clause requires and follow it.

This thesis requires a defense, of course. The fact that agency decision making on severability is typically better than judicial decision making does not necessarily entail that a reviewing court should always defer to an administrative severability clause. A reviewing court's severability decision might be more prudent in some cases if it could draw upon an agency's technical expertise. But not every severability decision will be highly technical. Similarly, the promulgation of some administrative severability clauses may not have involved participation by the public and may not have engendered any great reliance interests. This might lead some to conclude that the deference framework we propose is over-inclusive. One might argue that the fact that agencies are often superior decision makers about severability supports a deference framework more akin to the Skidmore regime, according to which the degree of deference that a severability clause receives should vary with a rule's technical complexity; the extent to which the agency's expertise and democratic accountability informed its adoption of the severability clause; and the extent to which the public has relied on the severability clause. ${ }^{219}$

219. Cf. Stephenson \& Pogoriler, supra note 47 , at 1458 (making a similar point about the domain of Seminole Rock deference). 
We must therefore defend our choice of a more rule-like framework over a standard-like framework. ${ }^{20}$ An extensive literature addresses the considerations that should lead one to favor (or not favor) a rule over a standard. ${ }^{221}$ The primary drawback of rules is that they are usually over- or under-inclusive with respect to the rulemaker's underlying policy goals. ${ }^{222}$ A rule-like framework may therefore lead a court to defer to an administrative severability clause that does not confer the benefits of administrative severability clauses discussed in Part I.B.

We believe, however, that rules have benefits that outweigh their drawbacks (vis-à-vis standards) in the case of deference to administrative severability clauses. First, a rule-like framework would better confine the discretion of lower courts, helping courts higher in the judicial hierarchy overcome principal-agent problems. ${ }^{223} \mathrm{~A}$ standard-like framework may influence lower courts to defer to administrative severability clauses not when those clauses, say, reflect the agency's administrative expertise, but when the court approves of the regulatory scheme that would result from the rule's remainder. Adopting a rule-like framework would help to curb this shirking tendency.

220. Kathleen Sullivan explains the choice between rules and standards:

A legal directive is "rule"-like when it binds a decisionmaker to respond in a determinate way to the presence of delimited triggering facts... A rule captures the background principle or policy in a form that from then on operates independently. ... [T] he rule's force as a rule is that decisionmakers follow it, even when direct application of the background principle or policy to the facts would produce a different result. . . A legal directive is "standard"-like when it tends to collapse decisionmaking back into the direct application of the background principle or policy to a fact situation. Standards ... giv[e] the decisionmaker more discretion than do rules. Standards allow the decisionmaker to take into account all relevant factors or the totality of the circumstances.

Kathleen M. Sullivan, The Supreme Court, 1991 Term-Foreword: The Justices of Rules and Standards, 106 HARV. L. REV. 22, 58-59 (1992).

221. See, e.g., Frederick Schauer, Playing by the Rules: A Philosophical Examination of RULE-BASED DeCISION-MAKING IN LAW AND IN LIFE 135-67 (1991); Isaac Ehrlich \& Richard A. Posner, An Economic Analysis of Legal Rulemaking, 3 J. LEGAL STUD. 257 (1994); Louis Kaplow, Rules Versus Standards: An Economic Analysis, 42 DUKe L.J. 557 (1992); Russell B. Korobkin, Behavioral Analysis and Legal Form: Rules vs. Standards Revisited, 79 OR. L. REV. 23 (2000).

222. See Mark Kelman, A Guide to Critical Legal Studies 40-41 (1987); SCHaUer, supra note 221, at 31-34; Korobkin, supra note 221, at 36-37; Merrill, supra note 72, at 826; Sullivan, supra note 220 , at 58 .

223. See Korobkin, supra note 221, at 38-39; Merrill, supra note 72, at 820-21; Vermeule, supra note 78 , at 355 . 
Second, a rule-like framework would be more predictable and thus would encourage the development of investment-backed expectations. ${ }^{224}$ As discussed in Part I.B.3, predictability in the law has a number of cost-saving advantages for agencies and regulated entities alike. Because agencies can better predict the effect of a severability clause, they can choose how to use their rulemaking resources most efficiently. If an agency is relatively certain that a court will defer to a severability clause, for example, it may choose to promulgate a set of substantive regulations as a single rule rather than divide the regulations across several rules. The agency might also devote fewer agency resources to explaining how the agency's administrative expertise informs the adoption of the severability clause. Similarly, regulated entities would be better positioned to organize their affairs around a regulatory scheme because they could more easily predict what the law would be if a challenged provision were eventually set aside. ${ }^{25}$ Finally, both agencies and regulated entities can save costs associated with the additional expense of litigating the application of a standard as opposed to the application of a rule. ${ }^{226}$

We also doubt that the over-inclusiveness problem is very severe in the case of a rule-like deference framework for severability clauses. As we explained in Part III.A, agencies tend not to include severability clauses in their rules lightly. When they do include a severability clause, they do so only after deliberation. Moreover, the cost of including a severability clause in a rule, as opposed to opining on severability in litigation, suggests that agencies will include these clauses prudently when they elect to bear these comparatively higher costs.

If one accepts our defense of Chevron-style deference to administrative severability clauses, one might then ask why our proposal is even more deferential than Chevron. At Chevron Step Two, courts defer only to reasonable agency interpretations of ambiguous federal statutes. Why then do we not propose that courts defer only to reasonable administrative severability clauses?

Deference only to putatively reasonable administrative severability clauses, however, would invite courts to determine for themselves whether a regulatory remainder is workable, thereby defeating the very purpose of the deference framework. At Chevron Step Two, the question of reasonableness is a question of legal meaning - that is, whether the agency has adopted a permissible construction of the statutory text (interpreted in light of the traditional tools of

224. See SCHAUER, supra note 221, at 137-45; Merrill, supra note 72 , at 822-23; Carol $M$. Rose, Crystals and Mud in Property Law, 40 STAN. L. REV. 577, 590-92 (1988); Vermeule, supra note 78 , at 356 .

225. See supra note 72 and accompanying text.

226. See SCHAUER, supra note 221, at 145-49; Merrill, supra note 72 , at 825 ; Vermeule, supra note 78 , at 356 . 
statutory construction). That question of reasonableness is still one within the institutional competence of the courts and does not require the reviewing court to evaluate the validity of the agency's underlying reasons for adopting its construction. By contrast, the question of reasonableness at Severability Step Two would require the reviewing court to determine whether it is permissible for the agency to maintain that the regulatory remainder is workable. This reasonableness question would inherently take the reviewing court outside of its institutional competence and collapse into an evaluation of the substantive regulatory merits of the agency's decision.

Furthermore, concerns about the unreasonableness of a severability clause are mostly allayed by our proposed residual arbitrary and capricious review, which we outlined in the previous section. If the regulatory remainder lacks a legal defect, such as being ultra vires or inconsistent with the agency's statement of basis and purpose, then the severability clause will likely not be unreasonable. Accordingly, the deference framework we propose can afford to be even more deferential than Chevron at Step Two without allowing unreasonable severability clauses to escape scrutiny.

\section{Step Zero: The Limits of the Deference Framework}

An agency may express its opinion on severability through agency actions other than including a severability clause in a rule. As we noted in Part II.B, ordinary agency practice is to opine on severability in trial and appellate briefs. An agency could also opine on severability by issuing any of a variety of informal agency documents, including interpretative rules and guidance manuals, which do not require notice and comment. ${ }^{227}$ We should therefore defend an underlying assumption of this Article - the assumption that the "domain"228 of a deference framework for severability should be limited to severability clauses. Put differently, we assume that courts should not give Chevron-style deference to other forms of agency action in which an agency might opine on severability.

Several Supreme Court cases might suggest that our deference regime should cast a wider net. The Supreme Court has addressed another "domain" question in the context of determining what agency actions should receive Chevron deference. ${ }^{229}$ In the leading case, United States v. Mead Corp., the Court

227. 5 U.S.C. $\$ 553$ (b)(A) (2012).

228. See generally Merrill \& Hickman, supra note 48.

229. See Barnhart v. Walton, 535 U.S. 212 (2002); United States v. Mead Corp., 533 U.S. 218 (2001) (holding that some agency statutory interpretations-particularly those contained in interpretive rules, informal orders, or other pronouncements issued without extensive procedures-are presumptively not entitled to Chevron deference); Christensen v. Harris Cnty., 
considered whether tariff classification rulings by the Customs Service were entitled to Chevron deference. ${ }^{230}$ The Court held that the tariff classification rulings at issue should not receive Chevron deference because they were not promulgated in the exercise of delegated authority to make rules with the force of law. The Court stated that notice-and-comment rulemaking (and formal adjudication) would presumptively receive Chevron deference but that other agency actions might also qualify for deference when "it appears that Congress delegated authority to the agency generally to make rules carrying the force of law, and that the agency interpretation claiming deference was promulgated in the exercise of that authority." 231 Thus, Mead expressly declined sharply to delimit Chevron's domain to legislative rules. ${ }^{232}$

The Supreme Court's Seminole Rock doctrine requires deference to an even larger set of agency actions. Auer itself, for example, involved an agency interpretation expressed in an amicus brief. ${ }^{233}$ In $M D / D C / D E$ Broadcasters $I I$, three judges on the D.C. Circuit suggested that Seminole Rock/Auer deference should apply to agency opinions on severability expressed in litigation. In that case, Judge David Tatel dissented from the D.C. Circuit's denial of rehearing en banc, in an opinion joined by then-Chief Judge Harry Edwards and Judge Judith Rogers. The FCC petitioned for rehearing, requesting that the court reinstate the remainder of a rule. Judge Tatel argued that the agency's opinion on the severability of its rule was an interpretation of the rule warranting Seminole Rock deference. ${ }^{234}$ Thus, if judicial deference to an agency's opinion on severability follows as a direct application of the Seminole Rock doctrine - that is, if courts should defer to administrative severability clauses pursuant to Seminole Rock - then perhaps the domain of our proposed deference framework should not be limited to severability clauses.

Although we agree that administrative severability clauses warrant deference under the Seminole Rock doctrine, we do not think that courts should give Chevron-style deference to agency opinions on severability other than severability clauses. ${ }^{235}$ In large part, our view is based on misgivings we share with sev-

529 U.S. 576,587 (2000) (holding that agencies' interpretations of statutes contained in opinion letters, policy statements, agency manuals, and enforcement guidelines are not entitled to Chevron deference).

230. Mead, 533 U.S. at 221.

231. Id. at 226-27 (emphasis added).

232. Merrill, supra note 72 , at 819-20.

233. See Auer v. Robbins, 519 U.S. 452, 461 (1997).

234. MD/DC/DE Broadcasters Ass'n v. FCC (MD/DC/DE Broadcasters II), 253 F.3d 732, 740 (2001) (citing Trinity Broad. of Fla., Inc. v. FCC, 211 F.3d 618, 625 (D.C. Cir. 200o)).

235. Several scholars have expressed a similar view in the context of determining Chevron's domain. See Robert A. Anthony, Interpretive Rules, Policy Statements, Guidance Manuals and the 
eral Justices on the Supreme Court about Seminole Rock itself. ${ }^{236}$ Recently, several Justices have criticized the Seminole Rock doctrine's tendency to encourage agencies to issue vague rules through notice-and-comment rulemaking and then clarify those rules through less formal, deliberative, and participatory procedures. ${ }^{237}$ Some Justices worry that the Seminole Rock doctrine creates incentives that ultimately undermine the accountability, transparency, and predictability of administrative rulemaking. ${ }^{238}$

There are similar concerns about incentives related to informal agency opinions on severability. Part II.B noted that the current severability doctrine does not create adequate incentives for agencies to promulgate severability clauses through notice-and-comment procedures. So giving the same Chevronstyle deference to agency opinions on severability expressed through informal agency actions would seem to undermine an agency's incentive to use more formal procedures. ${ }^{239}$

Chevron-style deference for informal agency opinions on severability would also generate uncertainty. A reviewing court cannot, as a practical matter, give Chevron-style deference to every agency informal opinion on severability because agency officials may express inconsistent opinions. Accordingly, a deference framework that would give Chevron-style deference to some informal

Like-Should Federal Agencies Use Them To Bind the Public?, 41 DUKE L.J. 1311 (1992); Robert A. Anthony, Which Agency Interpretations Should Bind Citizens and the Courts?, 7 YALE J. ON REG. 1 (1990); Lisa Schultz Bressman, How Mead Has Muddled Judicial Review of Agency Action, 58 VAND. L. REV. 1443 (2005); Eskridge, supra note 39, at 428; Merrill, supra note 72, at 831; Merrill \& Hickman, supra note 48 , at 835 .

236. Several current Justices have expressed doubts about the Seminole Rock doctrine. See Decker v. Nw. Envtl. Def. Ctr., 133 S. Ct. 1326, 1339 (2013) (Scalia, J., concurring in part and dissenting in part); Christopher v. SmithKline Beecham Corp., 132 S. Ct. 2156, 2168 (2012) (majority opinion by Justice Alito, in which Chief Justice Roberts and Justices Scalia, Kennedy, and Thomas joined); Talk Am., Inc. v. Mich. Bell Tel. Co., 131 S. Ct. 2254, 2266 (2011) (Scalia, J., concurring); Thomas Jefferson Univ. v. Shalala, 512 U.S. 504, 525 (1994) (Thomas, J., dissenting) (joined by Justice Ginsburg) (citing Pauley v. BethEnergy Mines, Inc., 501 U.S. 680,696 (1991)). In light of these criticisms, Court observers have wondered whether "a reconsideration of Auer is in the offing." Jonathan H. Adler, Auer Deference Still $U_{p}$ for Grabs?, VOLOKH CONSPIRACY (June 18, 2012, 11:36 AM), http://www.volokh.com/2012 /o6/18/auer-deference-still-up-for-grabs [http://perma.cc/J9-ULS6].

237. See Decker, 133 S. Ct. at 1341 (Scalia, J., concurring in part and dissenting in part) (" $A u$ $e r$ deference encourages agencies to be vague in framing regulations, with the plan of issuing 'interpretations' to create the intended new law without observance of notice and comment procedures." (internal quotation marks omitted)).

238. Id.

239. Cf. Robert A. Anthony, The Supreme Court and the APA: Sometimes They Just Don't Get It, 10 ADMIN. L.J. AM. U. 1, 12 (1996) (noting that deference "generates incentives to be vague in framing regulations, with the plan of . . creat[ing] the intended new law without observance of notice and comment procedures"); Manning, supra note 52, at 647-60. 
agency actions would have to apply a meta-standard for determining which agency actions warrant deference. ${ }^{240}$ Such a meta-standard, however, would likely produce inefficient litigation over the proper application of the standard in individual cases. Chevron-style deference for agency opinions on severability should therefore be reserved for severability clauses.

Reserving Chevron-style deference for severability clauses does not mean, however, that a reviewing court should give no deference to an agency's opinion on severability expressed in an informal agency action. We think informal agency opinions on severability should receive Skidmore deference. ${ }^{241}$ When notice-and-comment procedures are prohibitively time- and resource-consuming, informal agency opinions on severability can generate some of a severability clause's benefits. For example, even if a court does not defer to an agency's informal opinion on severability and strikes down a rule entirely, an informal opinion on severability could promote predictability because it could indicate how the agency is likely to proceed in the future. Suppose, for example, that an agency promulgates provisions $A$ and $B$ as part of regulation $R$ and states in an informal agency opinion that provisions $A$ and $B$ are severable. Assume further that a court later rules that provision $A$ is unlawful and inseverable from provision $B$. In this case, though the agency's opinion was ineffective at preventing a court from striking down the rule, the opinion would still give regulated entities some evidence that the agency is likely, in the future, to re-promulgate provision $B$ even in the absence of provision $A$.

Furthermore, since agencies do not use severability clauses frequently, ${ }^{242}$ agencies will likely clarify the severability of current regulations, if at all, through informal agency actions. Although we prefer that agencies opine on severability using severability clauses, amending existing rules that would benefit from an agency opinion on severability may be too cumbersome or costly. ${ }^{243}$ In these circumstances, we think an agency should be given incentives to opine on the severability of its rules, even if the agency does not express its opinion through a formal amendment to a rule. Accordingly, we think Skidmore deference is appropriate to encourage an agency to clarify its position on severability rather than remain silent.

240. For more on meta-standards, see generally Merrill, supra note $\mathbf{7 2 .}$

241. For a thorough analysis of the Skidmore doctrine, see Jim Rossi, Respecting Deference: Conceptualizing Skidmore Within the Architecture of Chevron, 42 WM. \& MARY L. REV. 1105, 1112-28 (2001).

242. See supra Part II.B.

243. Cf. Hoctor v. U.S. Dep't of Agric., 82 F.3d 165, 170 (7th Cir. 1996) ("[U]nless a statute or regulation is of crystalline transparency, the agency . . . cannot avoid interpreting it, and ... would be stymied in its enforcement duties if every time it brought a case . . . it had to pause for a bout, possibly lasting several years, of notice and comment rulemaking."). 
Under this approach, the various tiers of deference would appropriately match the diligence the agency used in expressing its opinion on severability. A reviewing court would reward an agency for an informal opinion on severability with deference tailored to the degree of care and expertise that the agency employed in adopting that opinion. Further, if an agency chose to invest even greater resources by promulgating a severability clause through the rigors of notice and comment, then a reviewing court would give additional deference in recognition of the greater rulemaking benefits that those procedures entail.

\section{CONCLUSION}

The current doctrine and agency practice on administrative severability clauses is unfortunate. Administrative severability clauses allow agencies to express their expert and popularly informed opinion on the severability of their rules. And if courts routinely deferred to those opinions, they would promote expertise, accountability, the rule of law, and efficiency in regulatory schemes.

However, the federal courts have implicitly analogized administrative severability clauses to severability clauses contained in statutes. Based on this analogy, federal courts have developed a doctrine in which the severability decision "will rarely turn on the presence or absence of ... a [n] [administrative severability] clause." 244 As a consequence, agencies have diminished incentives to promulgate their opinions on severability by means of notice-and-comment procedures. And the actual frequency with which agencies include severability clauses in their rules reflects these diminished incentives. Agencies have been content to leave the severability decision to the courts.

Current doctrine and agency practice suggest that courts need a deference framework for administrative severability clauses. Under this framework, courts should police the boundaries of the agency's lawmaking authority by ensuring that regulatory remainders are lawful. But when a regulatory remainder is lawful, a reviewing court should follow the opinion an agency expressed in a severability clause.

244. Cmty. for Creative Non-Violence v. Turner, 893 F. 2 d 1387 (D.C. Cir. 1990) (citation omitted) (internal quotation marks omitted). 
APPENDIX: ADMINISTRATIVE SEVERABILITY CLAUSES BY AGENCY

\begin{tabular}{lccc}
\hline \multicolumn{1}{c}{ Agency } & $\begin{array}{c}\text { Number of } \\
\text { Rules with } \\
\text { Severability } \\
\text { Clause }\end{array}$ & $\begin{array}{c}\text { Total } \\
\text { Number of } \\
\text { Rules (as } \\
\text { of October } \\
\text { 30, 2014) }\end{array}$ & $\begin{array}{c}\text { Percentage of } \\
\text { Total Rules } \\
\text { with a }\end{array}$ \\
$\begin{array}{l}\text { Severability } \\
\text { Clause }\end{array}$ \\
\hline Bureau of Consumer Financial Protection
\end{tabular}

245. (1) Mortgage Acts and Practices - Advertising (Regulation N), 12 C.F.R. $\$ 1014.7$ (2015); Mortgage Assistance Relief Services (Regulation O), 12 C.F.R $\$ 1015.11$ (2015);

(2) Real Estate Settlement Procedures Act (Regulation X), 12 C.F.R. $\$ 1024.22$ (2015); Real Estate Settlement Procedures Act (Regulation X), 76 Fed. Reg. 78,978, 78,998 (Dec. 20, 2011) (codified at 12 C.F.R. pt. 1024);

(3) Mortgage Servicing Rules Under the Real Estate Settlement Procedures Act (Regulation X), 12 C.F.R. $\$ 1024.22$ (2015); Mortgage Servicing Rules Under the Real Estate Settlement Procedures Act (Regulation X), 78 Fed. Reg. 10,695, 10,718 (Feb. 14, 2013) (codified at 12 C.F.R. pt. 1024).

246. Rights-of-Way, Principles and Procedures; Rights-of-Way Under the Federal Land Policy and Management Act and the Mineral Leasing Act, 43 C.F.R. $\$ 2801.8$ (2015).

247. Rules Implementing the Government in the Sunshine Act, 40 C.F.R. $\$ 1603.14$ (2014).

248. We determined this figure by searching Bloomberg Law for final rules that contain the phrase "Chemical Safety and Hazard Investigation Board." We then manually filtered the rules and identified ten hits.

249. (1) Real-Time Public Reporting of Swap Transaction Data, 17 C.F.R. $\$ 43.1$ (2014);

(2) Commodity Pool Operators and Commodity Trading Advisors, 17 C.F.R. $\$ 4.17$ (2014);

(3) Position Limits for Futures and Swaps, 17 C.F.R. $\$ 151.13$ (2014).

250. (1) Standards of Compliance for Abortion-Related Services in Family Planning Services Projects, 42 C.F.R. pt. 59 (2014);

(2) Standards for Privacy of Individually Identifiable Health Information, 45 C.F.R. pts. 160, 164 (2014);

(3) Applications for FDA Approval To Market a New Drug: Patent Submission and Listing Requirements and Application of 30-Month Stays on Approval of Abbreviated New Drug Applications Certifying that a Patent Claiming a Drug Is Invalid or Will Not Be Infringed, 21 C.F.R. pt. 314 (2014). 


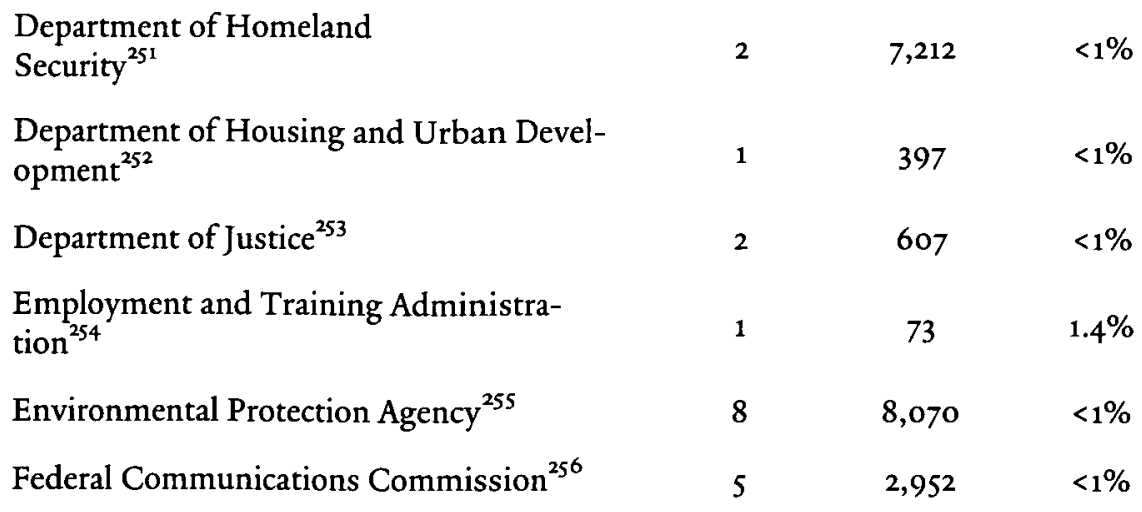

251. (1) Standards for Living Organisms in Ships' Ballast Waste Discharged in U.S. Waters, 33 C.F.R. pt. 151, 46 C.F.R. pt. 162 (2014).

(2) Chemical Facility Anti-Terrorism Standards, 6 C.F.R.pt. 27 (2014).

252. (1) Real Estate Settlement Procedures Act, 24 C.F.R. $\$ 3500.22$ (2014).

253. (1) International Terrorism Victim Expense Reimbursement Program, 28 C.F.R. $\$ 94.11$ (2014);

(2) Public Safety Officers' Death, Disability, and Educational Assistance Benefit Claims, 28 C.F.R. $\$ 32.4$ (2014);

(3) Public Safety Officers' Death, Disability, and Educational Assistance Benefit Claims, 28 C.F.R. $\$ 32.4$.

254. (1) Temporary Agricultural Employment of $\mathrm{H}-2 \mathrm{~A}$ Aliens in the Unites States; Modernizing the Labor Certification Process and Enforcement, 20 C.F.R. pt. 655.

255. (1) National Emissions Standards for Hazardous Air Pollutants from Secondary Lead Smelting, 40 C.F.R. pt. 63 (2014);

(2) Determination of Attainment of the 1-Hour Ozone National Ambient Air Quality Standards in the Sacramento Metro Nonattainment Area in California, 4o C.F.R. pt. 52 (2014);

(3) Nonattainment New Source Review (NSR), 40 C.F.R. pt. 51 (2014); Expansion of RCRA Comparable Fuel Exclusion, 40 C.F.R. pt. 261 (2014);

(4) Administrative Stay of Clean Air Interstate Rule for Minnesota; Administrative Stay of Federal Implementation Plan To Reduce Interstate Transport of Fine Particulate Matter and Ozone for Minnesota, 40 C.F.R. pts. 51, 52 (2014);

(5) Consolidated Federal Air Rule (CAR): Synthetic Organic Chemical Manufacturing Industry, 40 C.F.R. pts. 60, 61, 63, 65 (2014);

(6) Public Health and Environmental Radiation Protection Standards for Yucca Mountain, NV, 40 C.F.R. pt. 197 (2014);

(7) Regulation of Fuels and Fuel Additives: Modifications to Reformulated Gasoline Covered Area Provisions, 40 C.F.R. pt. 80 (2014).

256. (1) Rates for Interstate Inmate Calling Services, 47 C.F.R. pt. 64 (2014);

(2) Closed Captioning of Internet Protocol-Delivered Video Programming: Implementation of the Twenty-First Century Communications and Video Accessibility Act of 2010, 47 C.F.R. pts. 15, 79 (2014); 


$\begin{array}{lccc}\text { Federal Railroad Administration }^{257} & 4 & 176 & 2.3 \% \\ \text { Federal Trade Commission }^{258} & 13 & 206 & 6.3 \% \\ \text { Forest Service }^{259} & 5 & 159 & 3.1 \%\end{array}$

(3) Implementation of the Commercial Advertisement Loudness Mitigation (CALM) Act, 47 C.F.R. pts. 73, 76 (2014);

(4) 2006 Quadrennial Regulatory Review - Review of the Commission's Broadcast Ownership Rules and Other Rules Adopted Pursuant to Section 202 of the Telecommunications Act of 1996, 47 C.F.R. pt. 73 (2014);

(5) Broadcast Ownership Rules, Cross-Ownership of Broadcast Stations and Newspapers, Multiple Ownership of Radio Broadcast Stations in Local Markets, and Definitions of Radio Markets, 47 C.F.R. pt. 73 (2014).

257. (1) Use of Locomotive Horns at Highway-Rail Grade Crossings, 49 C.F.R. $\$ 222.3(b) (2014);

(2) Positive Train Control Systems, 49 C.F.R. $\$ 236.1$ (2014);

(3) Use of Locomotive Horns at Highway-Rail Grade Crossing, 49 C.F.R. $\$ \$ 222.3$;

(4) Use of Locomotive Horns at Highway-Rail Grade Crossing, 49 C.F.R. $\$ \$ 222.3$.

258. (1) Business Opportunity Rule, 16 C.F.R. $\$ 437.10$ (2014);

(2) Children's Online Privacy Protection Rule, 16 C.F.R. $\$ 312.12$ (2014);

(3) Disclosure Requirements and Prohibitions Concerning Franchising,16 C.F.R. $\$ 436.11$ (2014);

(4) CAN-SPAM Rule, 16 C.F.R. $\$ 316.6$ (2014);

(5) Prohibitions of Energy Market Manipulation Rule, 16 C.F.R. $\$ 317.5$ (2014);

(6) Telemarketing Sales Rule, 16 C.F.R. $\$ 310.9$ (2014);

(7) Mortgage Assistance Relief Services, 16 C.F.R. pt. 322 (2014);

(8) Mortgage Acts and Practices - Advertising, 16 C.F.R. $\$ 321.7$ (2014).

(9) Telemarketing Sales Rule, 16 C.F.R. $\$ 310.8$ (2014).

(10) CAN-SPAM Rule, 16 C.F.R. $\$ 316.6$;

(11) Amendment of Rules Under the FACT Act, 16 C.F.R. $\$ 604.1$ (2014);

(12) Contact Lens Rule, 16 C.F.R. $\$ 315.10$ (2014);

(13) Definitions and Implementation Under the CAN-SPAM Act, 16 C.F.R. $\$ 316.6$ (2014).

259. (1) National Forest System Land Management Planning, 36 C.F.R. $\$ 219.18$ (2015); National Forest System Land Management Planning, 77 Fed. Reg. 21,162, 21,244, 21,27o (Apr. 9, 2012) (codified at 36 C.F.R. pt. 219);

(2) National Forest System Land Management Planning, 73 Fed. Reg. 21,468, 21,502, 21,512 (Apr. 21, 2008) (codified at 36 C.F.R. pt. 219);

(3) Special Areas, 36 C.F.R. $\$ 294.18$ (2015); Special Areas; Roadless Area Conservation, 66 Fed. Reg. 3,244, 3,260 (Jan. 12, 2001) (codified at 36 C.F.R. pt. 294);

(4) National Forest System Land Management Planning, 70 Fed. Reg. 1023, 1052, 1060 (Jan. 5, 2005) (codified at 36 C.F.R. pt. 219); 


\begin{tabular}{lccc} 
National Indian Gaming Commission $^{260}$ & 1 & 41 & $2.4 \%$ \\
$\begin{array}{l}\text { National Labor Relations Board } \\
\text { Nat }\end{array}$ & 1 & 22 & $4.5 \%$ \\
$\begin{array}{l}\text { National Oceanic and Atmospheric Admin- } \\
\text { istration }\end{array}{ }^{262}$ & 1 & 4,346 & $<1 \%$ \\
National Park Service $^{263}$ & 1 & 75 & $1.3 \%$ \\
Nuclear Regulatory Commission $^{264}$ & 1 & 439 & $<1 \%$ \\
Occupational Safety and Health Admin- $^{265}$ & 1 & 148 & $<1 \%$ \\
Pstration $^{\text {Postal Service }}$ & & & $<1 \%$ \\
\hline
\end{tabular}

(5) Special Areas; State Petitions for Inventoried Roadless Area Management, 70 Fed. Reg. 25,654, 25,655, 25,662 (May 13, 2005) (codified at 36 C.F.R. pt. 294).

260. Technical Standards for Electronic, Computer, or Other Technologic Aids Used in the Play of Class II Games, 25 C.F.R. $\$ 547.5$ (2014).

261. Representation - Case Procedures, 29 C.F.R. pts. 101, 102 (2014).

262. (1) Magnuson-Stevens Fishery Conservation and Management Act Provisions; Fisheries of the Northeastern United States; Northeast Region Standardized Bycatch Reporting Methodology Omnibus Amendment, so C.F.R. pt. 648 (2014).

263. Concession Contracts, 36 C.F.R. $\$ 51.103$ (2014).

264. Disposal of High-Level Radioactive Wastes in a Proposed Geologic Repository at Yucca Mountain, NV, 10 C.F.R. $\$ 63.343$ (2014).

265. Cranes and Derricks in Construction, 29 C.F.R. $\$ 1926.1442$ (2015).

266. The Board of Governors of the U.S. Postal Service Bylaws of the Board of Governors, 39 C.F.R. $\$ 2.6$ (2015). 
